انتخاب نواحى مناسب براى كاشت حرا Avicennia marina در منطقه ساحلى بوشهر با

استفاده از روش بهترين - بدترين و تصميم گيرى جندمعياره

محمد گلستانى ' و فاضل اميرى ب*

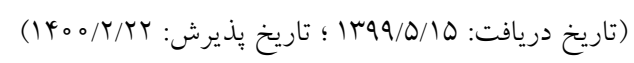

جكيده

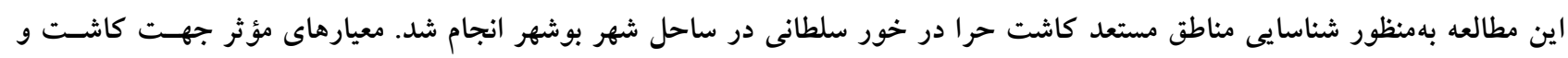

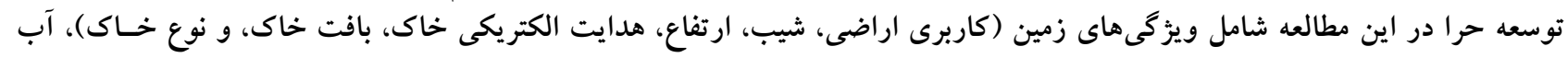

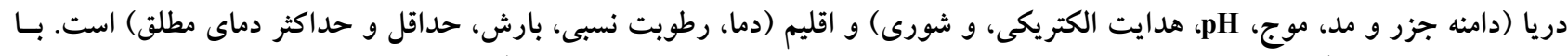

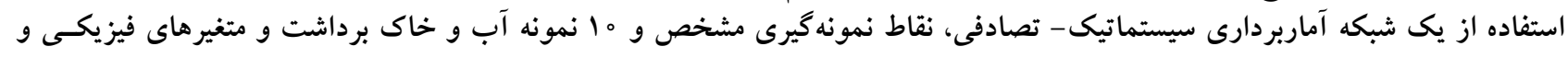

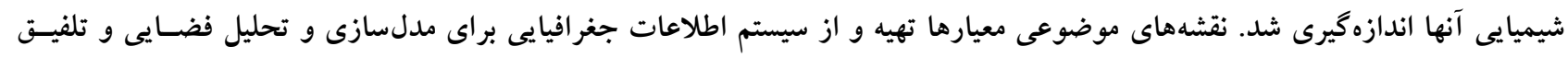

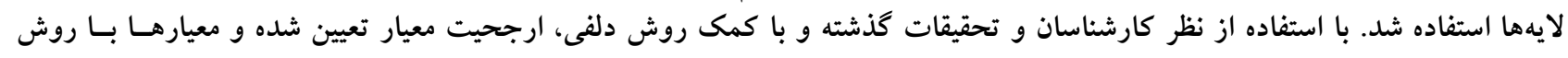

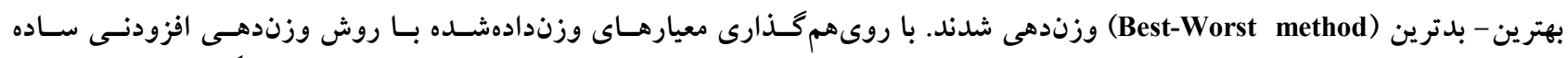

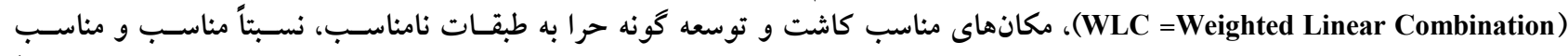

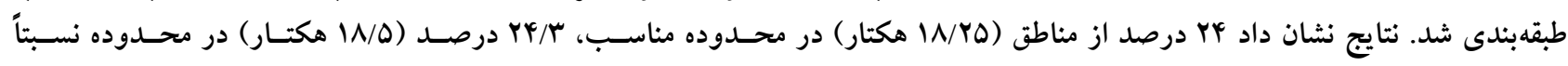

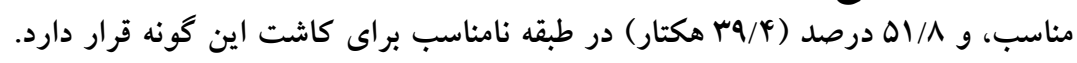

وازههاى كليدى: مانگرو، مكانيابى، سامانه اطلاعات جغرافيايى، روش بهترين - بدترين، ارزيابى جندمعياره، خور سلطانى، منطقه ساحلى شهرى 
يكى از روشهاى تصميم گيرى جندمعياره، تعدادى گزينه با توجه

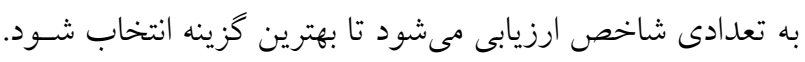

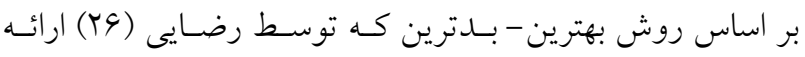

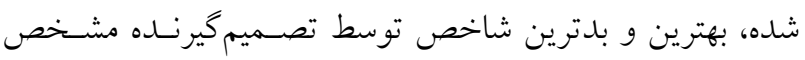

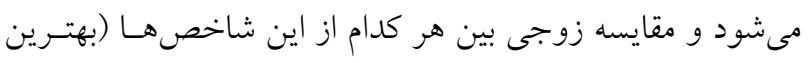

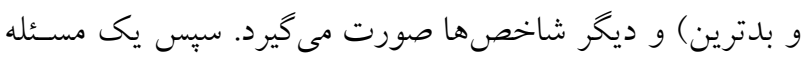

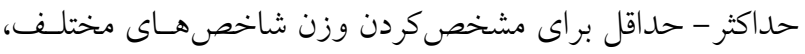
فرمولبندى و حل مىشود. همجنين در اين روش رابطهاى بـراى

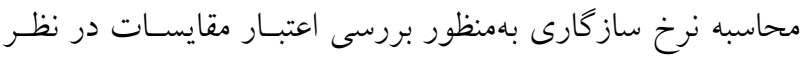

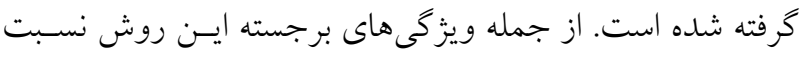

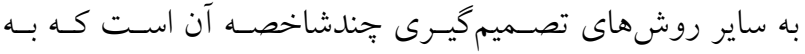
دادههاى مقايسهاى كمتــى نيـاز دارد، و همجنــين بـه مقايسـهاى استوارتر منجر مىشود، بدين معنا كه جوابهاى قابل اطمينانترى ارائه مى كند (9).

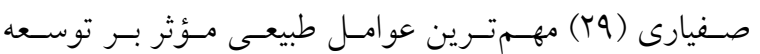

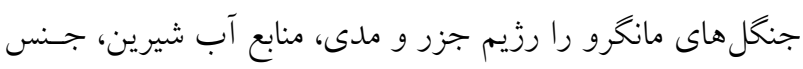

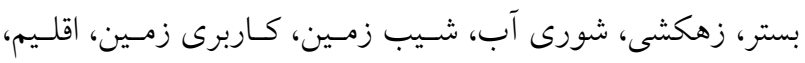

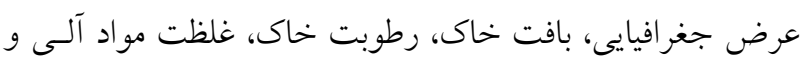

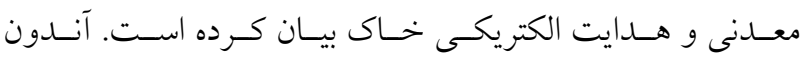

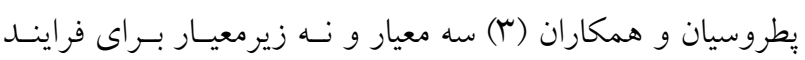

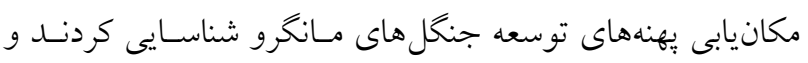

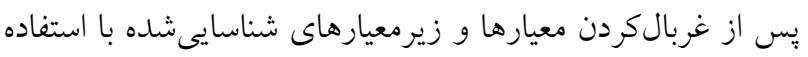

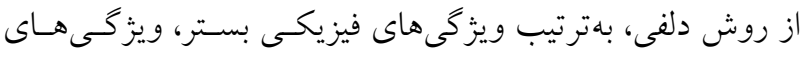
شيميايى بستر، جزر و مل موج، دماى هوا، كيفيت آب، نـونع اقلسيم

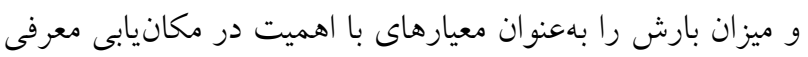

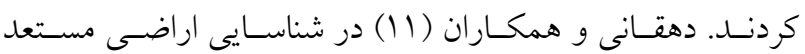
توسعه جنغل هاى مانكرو در منطقه هلر جزيــره قشـم، مهـمتـرين

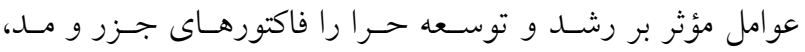

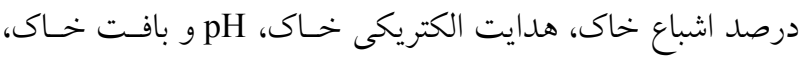
منيزيم، سديم، نسبت جذب سديم و ميزان سـديم تبـادلى خـاك معرفسى كردنـــ. نـاكلركن و همكـاران (Yr) فاكتورهـاى درجـهـ حرارت، شكل و خصوصيات ساحل، شورى آب و جزر و مــ را

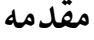

با توجه به تخريب بسيارى از رويشگاههاى مانخرو دنيـا، توجـهـ

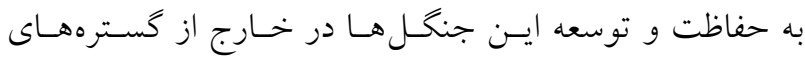

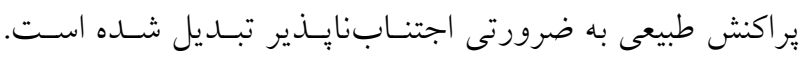

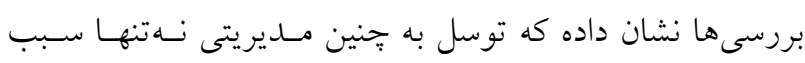

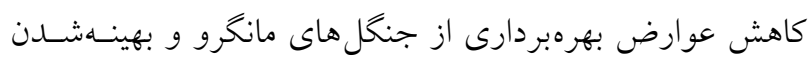

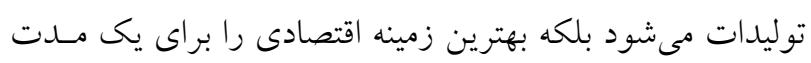

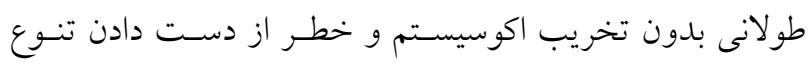

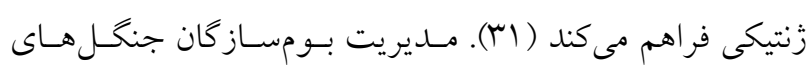

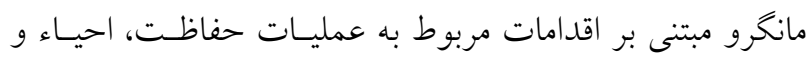

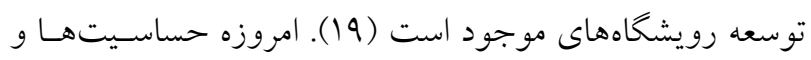
توجههاى بين المللى در مورد مانخروها، دولت را بر آن داشته تا تأنا

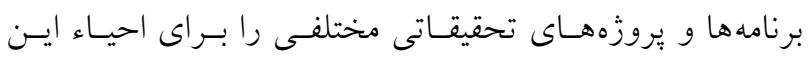

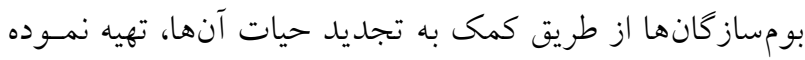

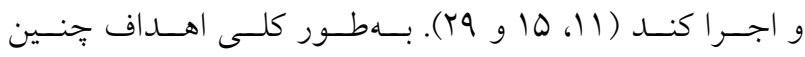

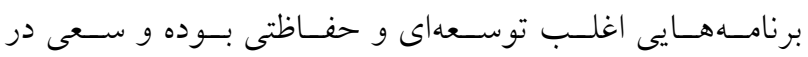
باز كرداندن اكوسيستم به حالت طبيعى آن دارند.

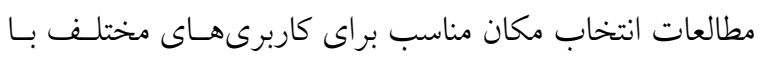

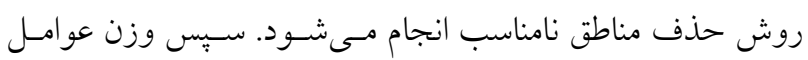

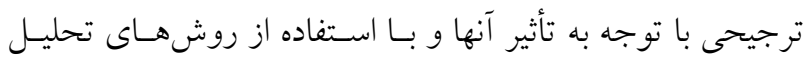

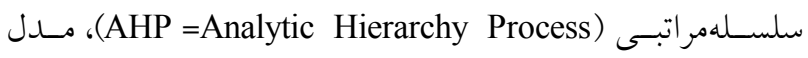

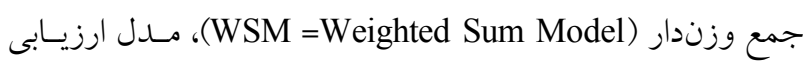
توليــ وزنس تجمعى ( Weighted Aggregated Sum Product Technique for (WASPAS =Assessment $=$ Order of Preference by Similarity to Ideal Solution TOPSIS

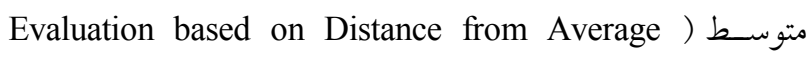
Fuzzy (EDAS =Solution FAHP=Analytic Hierarchy Process تخمين زده مىشود. در نهايت، تجزيه و تحليل بوشش وزنسى در

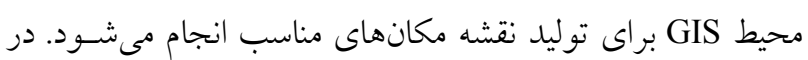

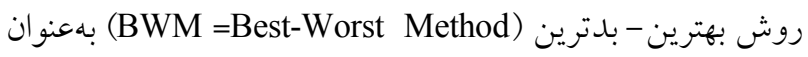


داد كه بهترين شرايط براى استقرار اين گونه در دامنه pH آب بين

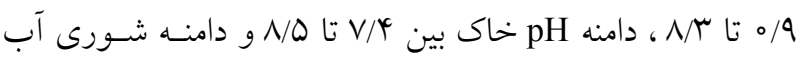

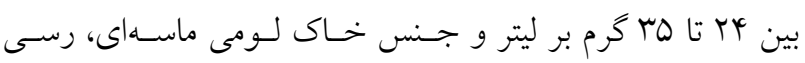

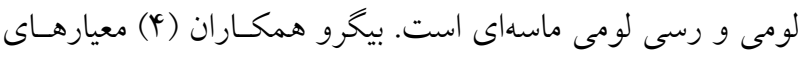

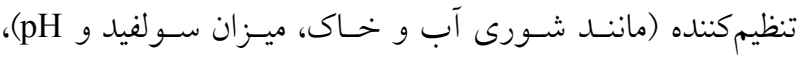

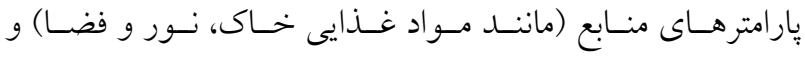

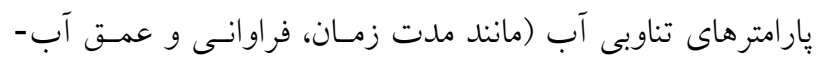

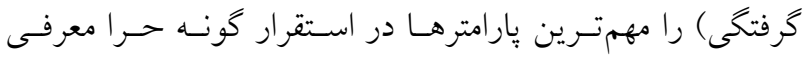
كردند. ناظم و همكاران (rT) در خصوص كاشت حرا بـهمنظور

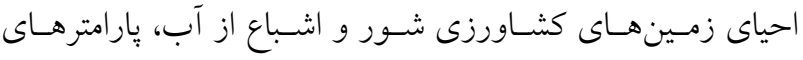

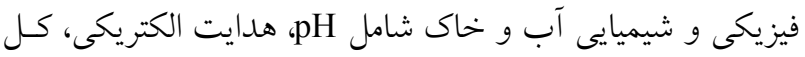
جامدات محلول، اكسيزن محلول و درصد شورى را در زيستكاه

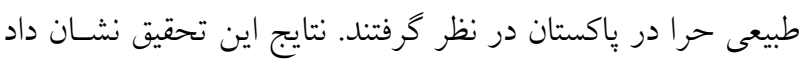

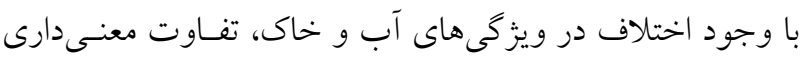

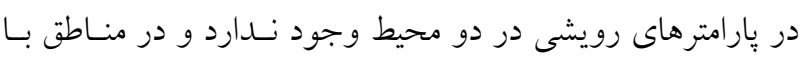

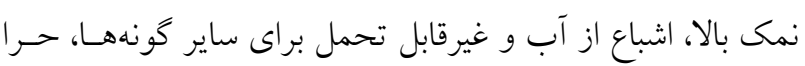
يكى از معدود كونههايى است كه بقا مى يابد.

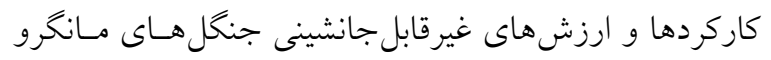

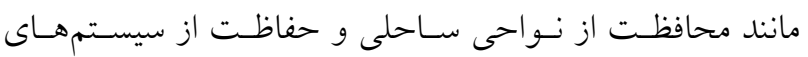

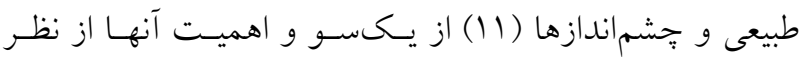

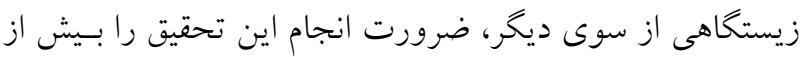

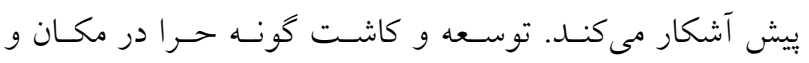

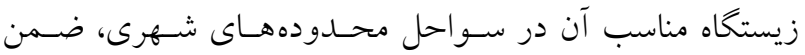

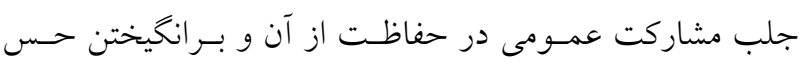
زيباشناختى عمومى، بهعنوان يكى سبر حفاظتى در نخهداشـت و صيانت از سواحل بسيار مفيد است. با توجه به يتانسيل سـواحل

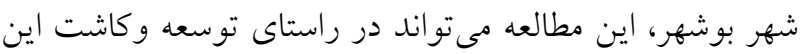

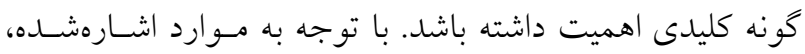
اين تحقيق در راستاى بتانسيل سنجى و شناسايى اراضى مستعد

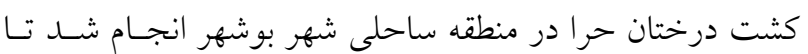
مناطق مناسب براى كاشت كونه حـرا شناسـيى شـده و امكــان توسعه جنغل كارىهاى مانكرو در منطقه مورد مطالعه با استفاده

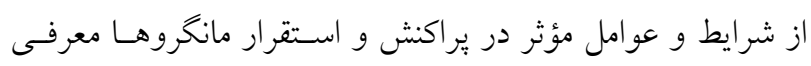

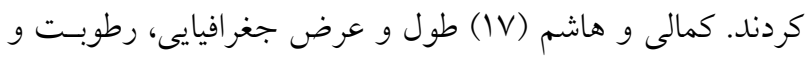

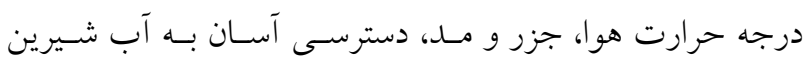

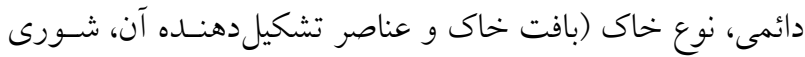
و اسيديته) را از عوامل مؤثر بر شكل گيرى مانكروها بيان كردهاند. نتايج اين بررسى نشان داد كه استقرار موجشـكن در منطقـهاى بـ بـا

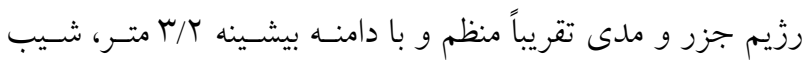

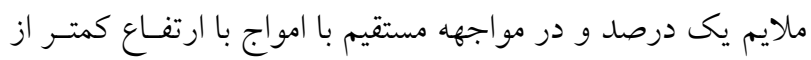

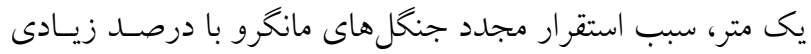
از گونه حرا شده است. شهادتحسين و همكاران (ب) با در نظر

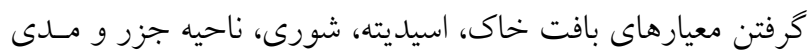

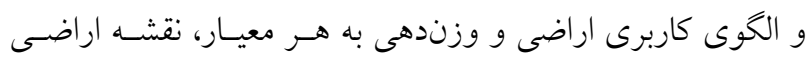

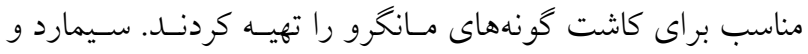

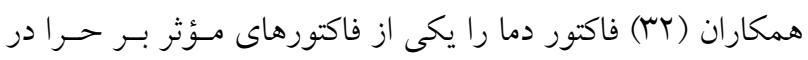

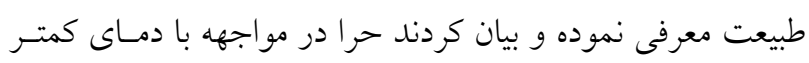

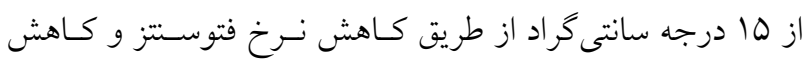

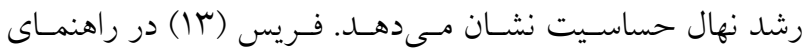
احياى زمين جهت كشت كونه حرا بيان كرد كه بارامترهاى خـاك

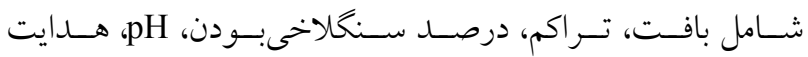

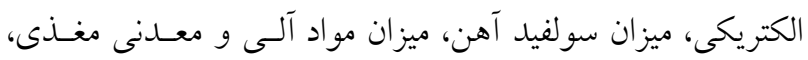

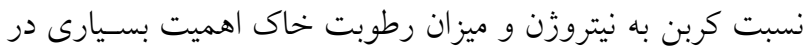

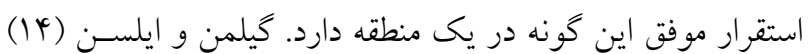

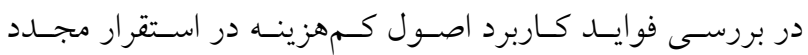
جنكل هاى مانكرو در آمريكا، عوامل مهم تعيين كنــده در اسـتقرار مجدد و معرفى موفق گونه مانكرو در يك منطقه را شامل فراوانى

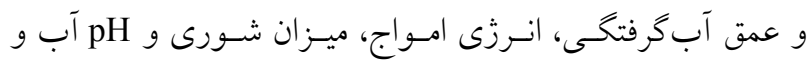
خاك، نوع و بافت خاك، مواد غذايى خاك و شيب دانستند. بهـلا

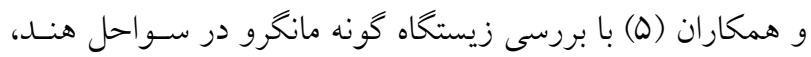
ضمن اشاره به اهميت عناصر موجود در خاك در موفقيت كاشت

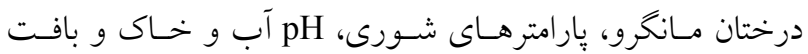

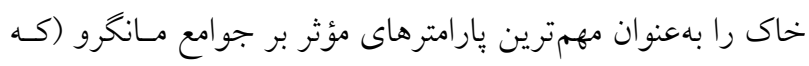

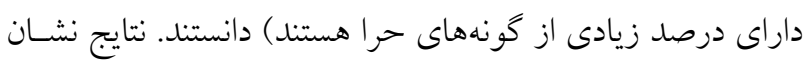


يوشش منطقه، يوشش بِّكى تجمع جلبك هــاى Stramatolik بـر

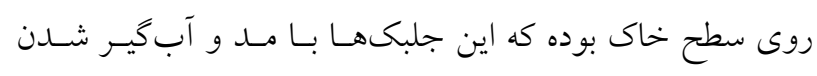
منطقه، فعاليت خود را آغاز مى كنند.

دادههاى مورد استفاده منابع اطلاعات اوليه مورد استفاده در ايسن مطالعسه شـامل تصـوير

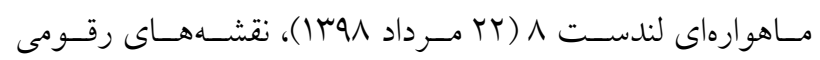

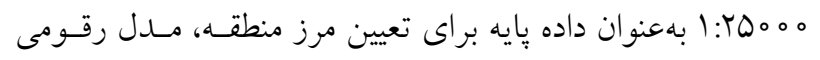

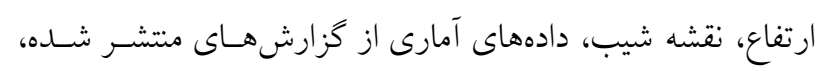
دادههاى ميدانى برداشتشده با اسـتفاده از سـامانه موقعيـتيـاب جهانى (كارمين مدل GPS-MAP 78s با دقت مكـانى يـك متـر) جهت ارزيابى نقشه واقعيت زمينى، نقشه كاربرى اراضسى و نقشـه

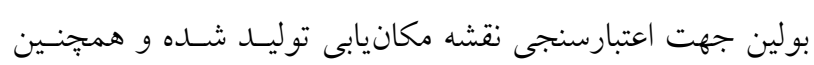

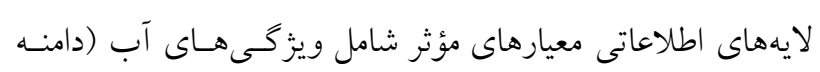
جـزر و مـد، مـوج، pH آب، هــدايت الكتريكسى و شـورى آب)، ويز كىهاى زمسين (كـاربرى اراضسى، عـرض جغر افيـايى، شـيب، ارتفاع، هدايت الكتريكى خاك، بافت خاك و نوع خاك)، و اقليم (متوسط بارش سـاليانه، رطوبـت نسـبى، متوسـط دمـاى سـاليانه،

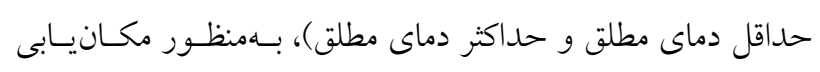
مناطق مستعد توسعه و گسترش جنگل هاى مانخرو مىباشد.

\section{روث تحقيق}

جهت انتخاب منطقه مناسب كاشت كونسه Avicennia marina سه معيار و IV زيرمعيار شامل ويز كىهـاى آب (دامنـه جـزر و

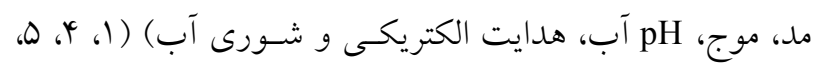

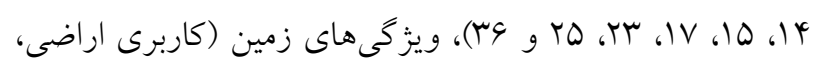
عرض جغرافيايی، شيب، ارتفاع، هدايت الكتريكى خاك، بافـت

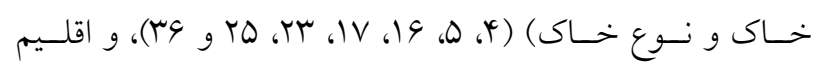
(متوسط بارش ساليانه، رطوبت نسـبى، متوسـط دمـاى سـاليانه،

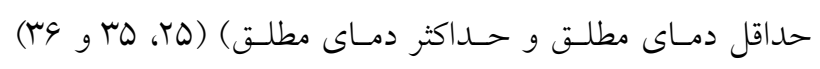
انتخاب شد (جدول (). لايههاى اطلاعـاتى ايسن معيارهـا تهيـه

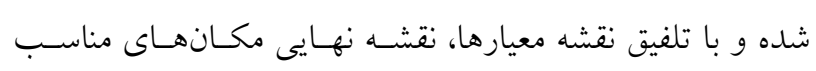

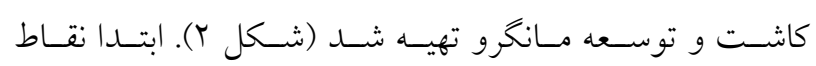

$$
\text { از روش بهترين - بلدترين (BWM) فراهم شود. }
$$

\section{مواد و روشها}

منطقه مورد مطالعه

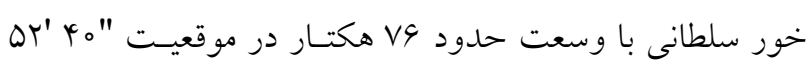

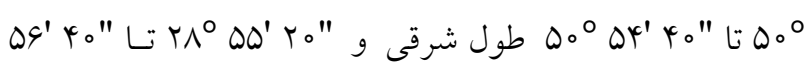

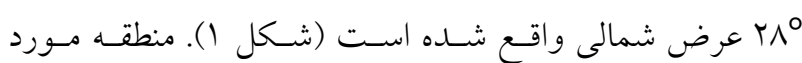
مطالعه، يوشش دست كاشت مانخرو در خور سلطانى در ورودى شهر بوشهر است. اين خور در اثر فعل و انفعالات جزر و مـدى و بهصورت طبيعى ايجاد شده كه در ابتدا از عمق ه/W تا ه ا متر برخوردار بوده اسـت. طـول ايسن خـور تـا خـور يسودر (محسل اسكلههاى منطقـه دوم دريـايى، صــرا، و كشـتىسـازى شـهيد

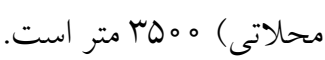

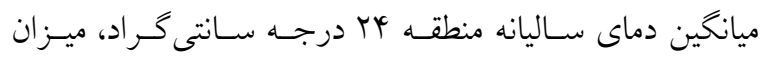

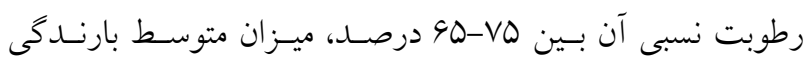

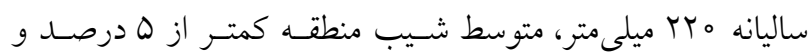
متوسط ارتفاع كمتر از † متر است (Y). تمام محدوده دشـتهــاى ساحلى منطقه در هنخام جــزر و مــدهاى بلنــد در زيـر آب قــرار مى گيرد. خاى منطقه مورد مطالعه آبرفتى بوده و حاصل فرسـايش اراضى مجاور و رسوبكَذارى است. خاكهاى اين منطقـه جـزء

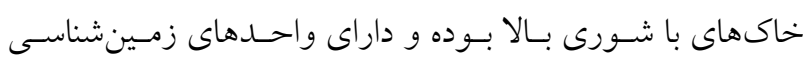
سابخا (Sabkha) مىباشد كه اين واحدها به سمت دريا كسترش

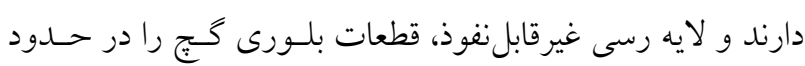

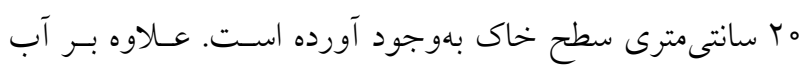

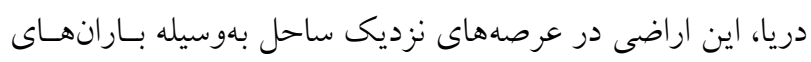

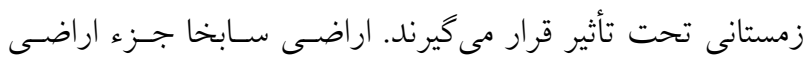

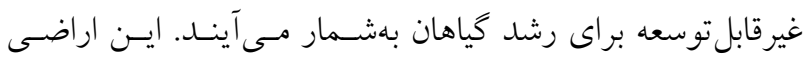

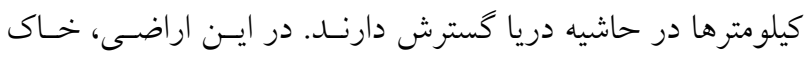

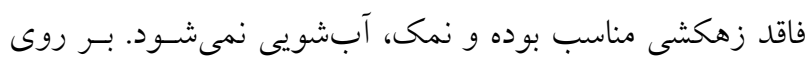
اين اراضى، سابقه رويش هيج بوشـش گيـاهى وجـود نداشـته و

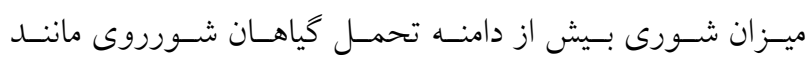
Avicennia marina هالوفيتها نيز در اين اراضى بهصورت طبيعى وجود نــدارد. تنهـا 


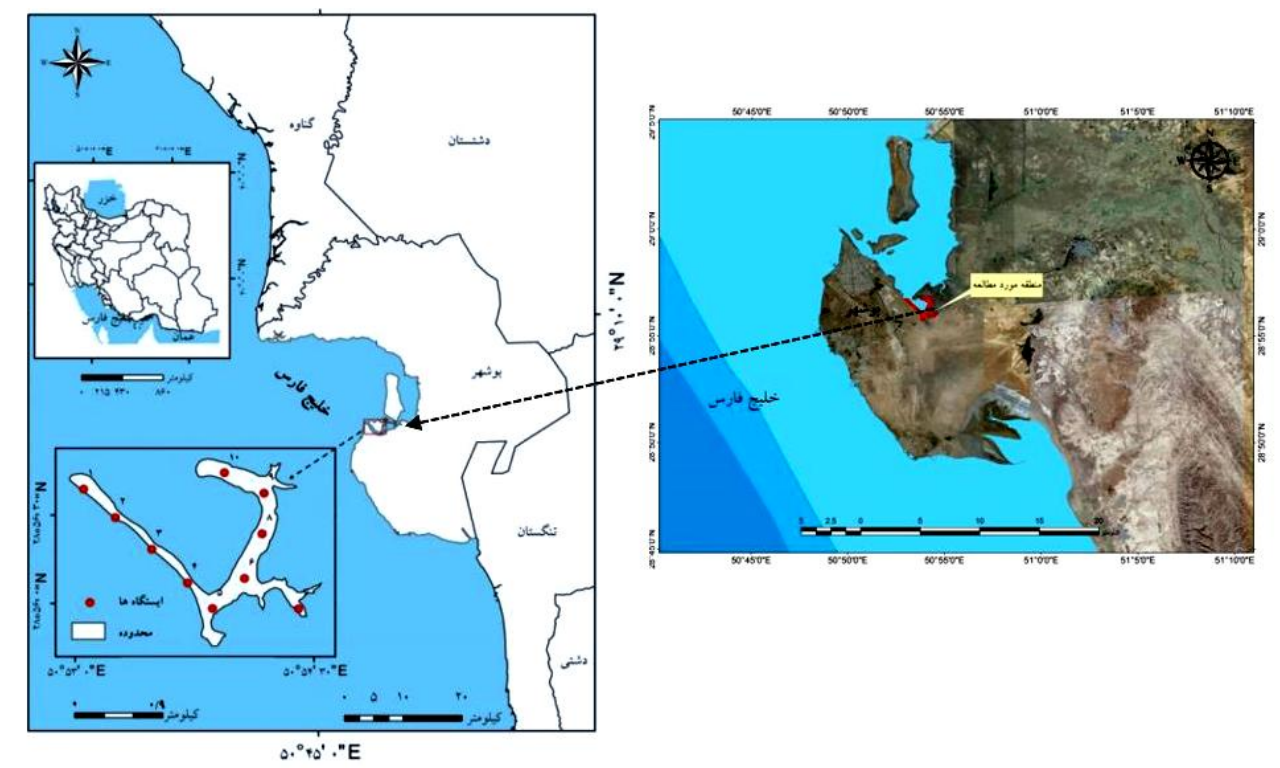

شكل ا. منطقه مورد مطالعه و موقعيت نقاط نمونهبردارى در محدوده جزر و مدى (رنخى در نسخه الكترونيكى)

جدول ا. طبقات نقشه معيارها و زيرمعيارها در مكانيابى محل كاشت حرا

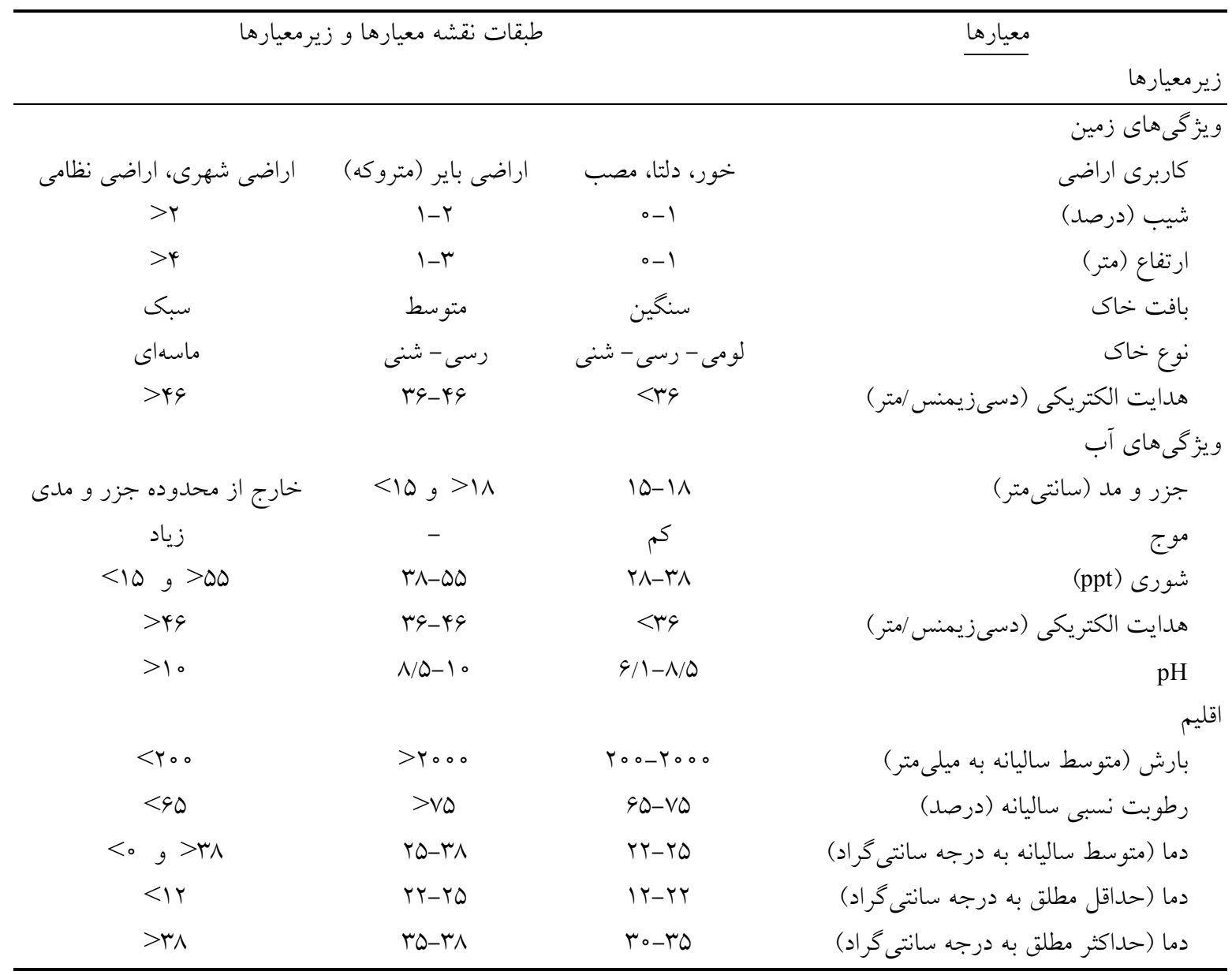




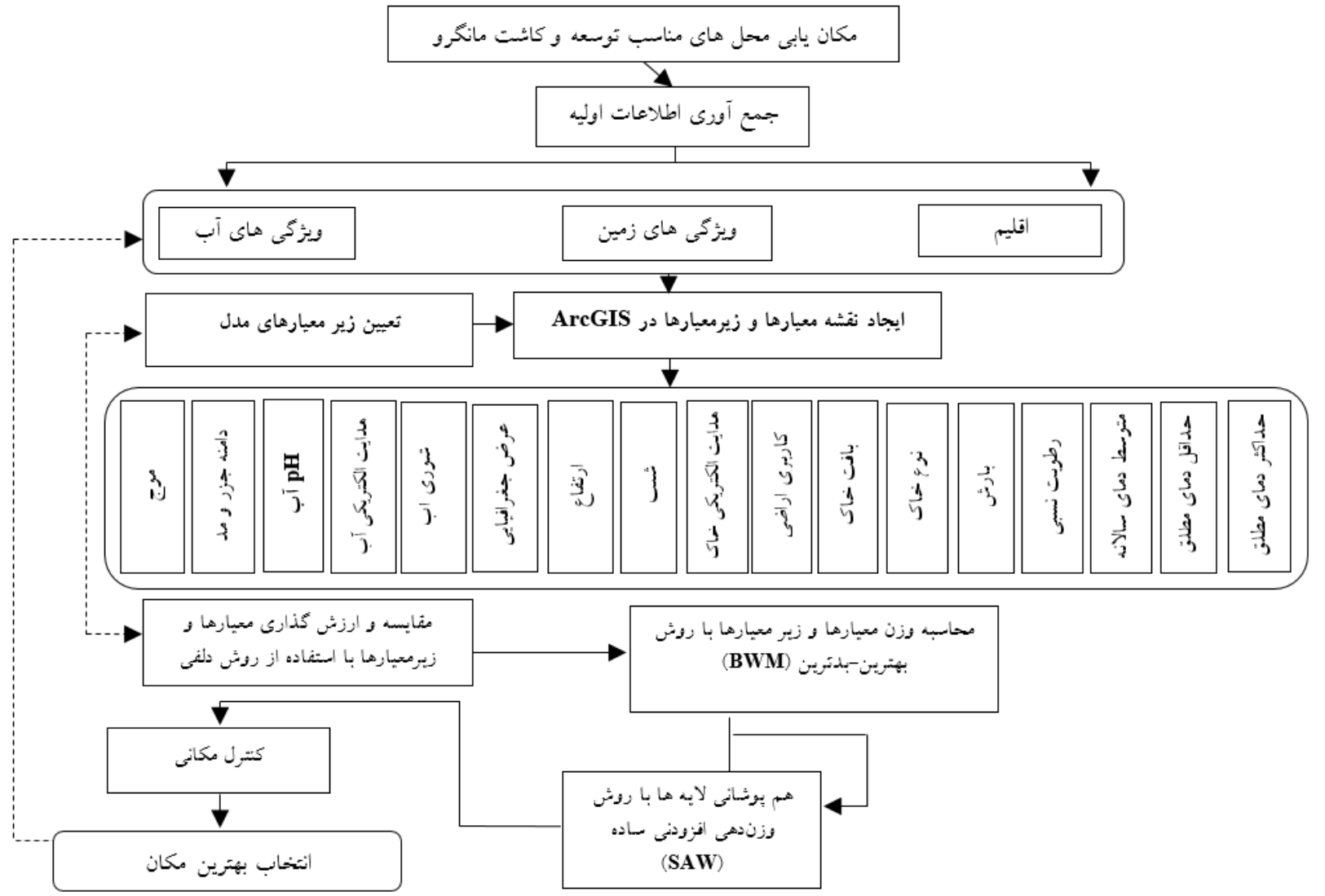

شكل r. مراحل تهيه و تلفيق لايههاى اطلاعاتى و تهيه نقشه نهايى مكانهاى مناسب توسعه و كاشت مانكرو

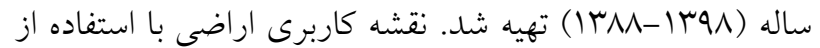

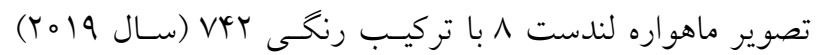

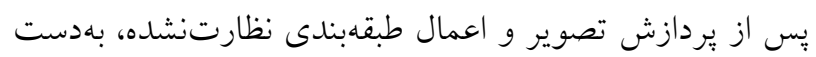

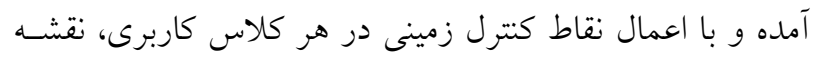
كاربرىها با استفاده از بارزسازى تصوير و تفسير بصـرى (YN (Y)،

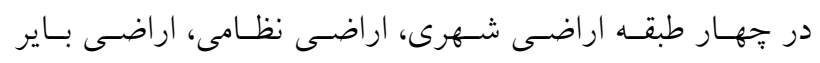

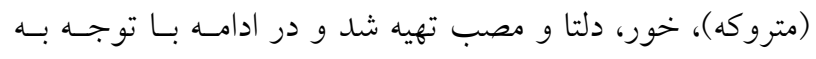

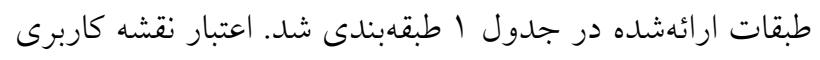
اراضى با استفاده از تصوير كو گلارث (Google Earth نقطه كتترل زمينى كه بهصورت سيستماتيك- تصادفى با استفاده

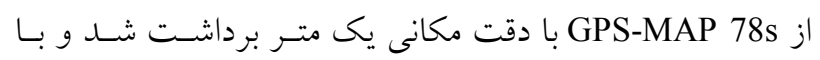

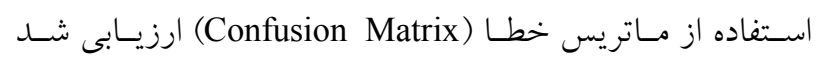

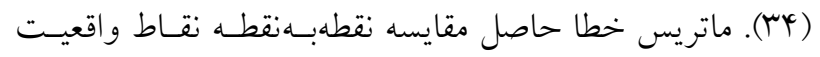

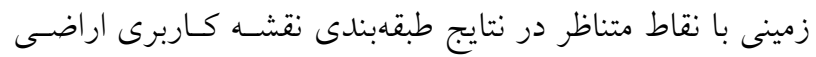

نمونهبردارى بـر روى نقشـه مشـخص شـــ و در هـر ايستخاه،

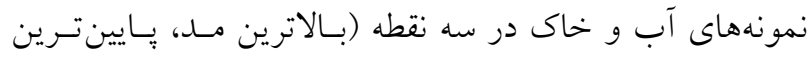

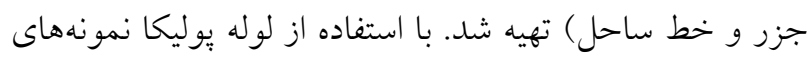

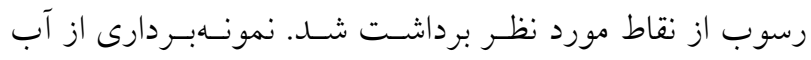

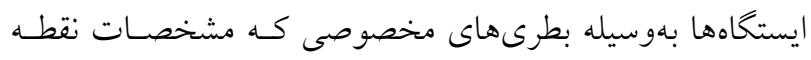

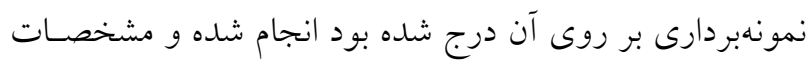
شيميايى آب در آزمايشكاه تعيين شد.

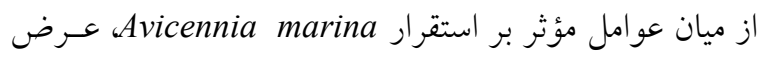

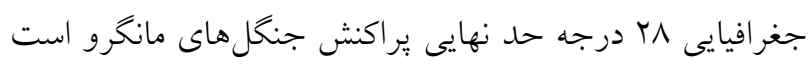

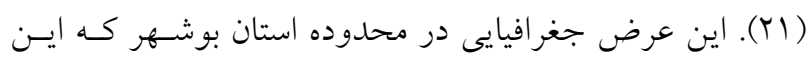
تحقيق در آن انجام شده قرار دارد. بهدليل اينكـهـ كـل منطقـهـ در

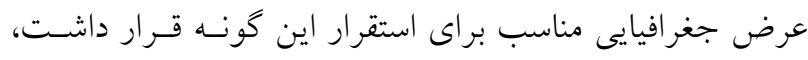

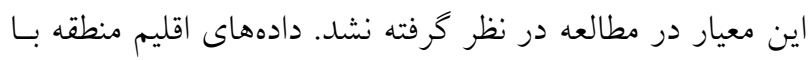

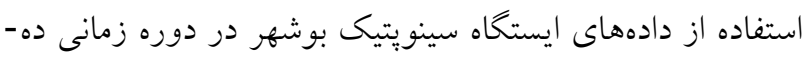


نقطه نمونهبردارىشده (شكل ())، نقشه درونيابى تهيـه شــه و سبس با استفاده از تابع خطى كاهشى، نقشه فازى اين لايه تهيـه

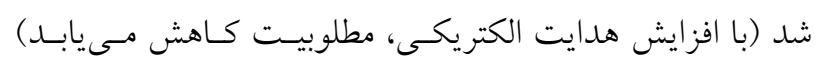

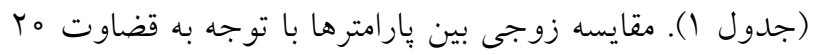

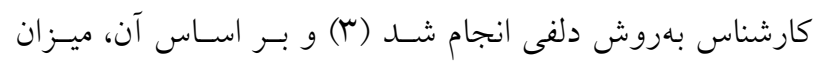

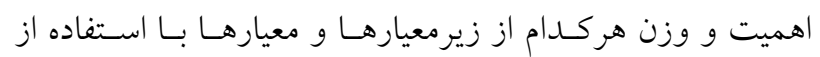

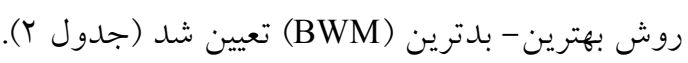

مراحل روش بهترين - بدترين (BWM)

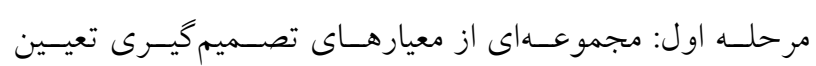

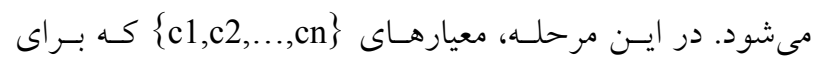

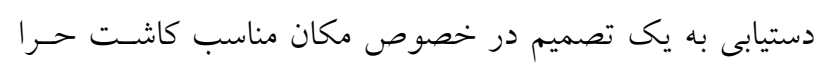

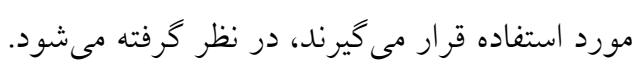

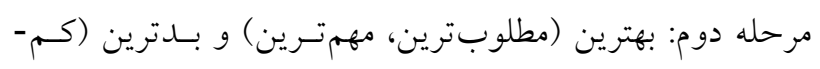

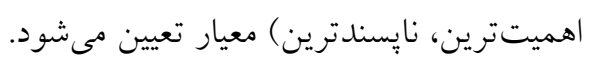

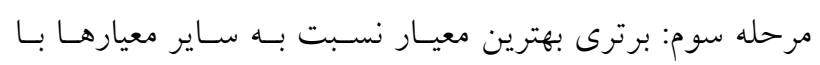

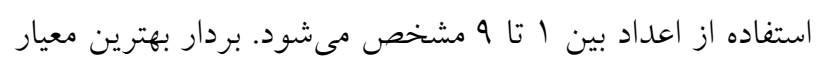

$$
\text { نسبت به ساير معيارها بلصورت زير تعريف مىشود. }
$$

$\mathrm{AB}=\left(\mathrm{a}_{\mathrm{B} 1}, \mathrm{a}_{\mathrm{B} 2}, \ldots ., \mathrm{a}_{\mathrm{Bn}}\right)$

در اين رابطه؛ aBj برترى بهترين معيار B را براى معيار j نشـان

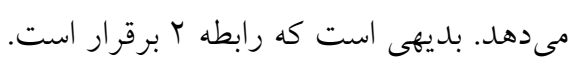

$\mathrm{a}_{\mathrm{BB}}=1$

مرحله جهارم: برترى تمام معيارها نسبت بـهـ بــترين معيـار بـاــا

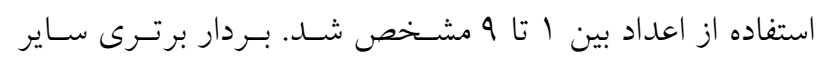

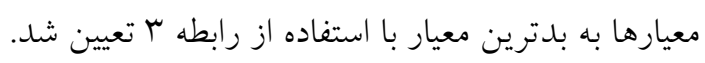
$A w=\left(a_{1 w}, a_{2 w}, \ldots, a_{n w}\right) T$

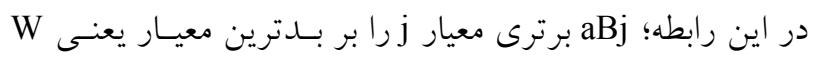
نشان مى دهد. بديهى است كه رابطه ب برقرار است. $\mathrm{a}_{\mathrm{ww}}=1$

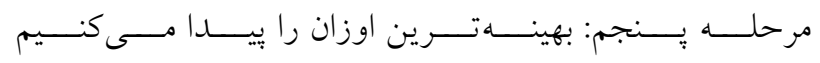
(w $\left(w_{1}{ }^{*}, w_{2}{ }^{*}, \ldots, w n{ }^{*}\right)$ آن، براى هر زوج
تطبيق - دادهشده بر روى تصوير گو گلارث است. نقاط برداشـت

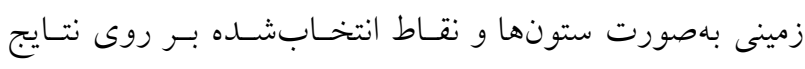

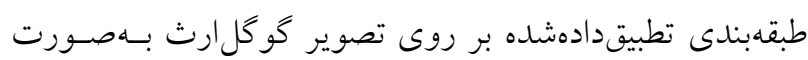

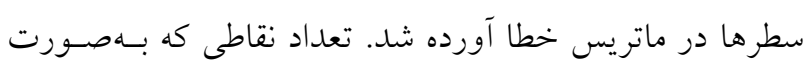

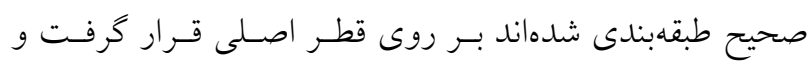

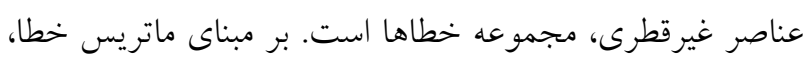

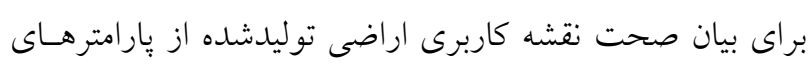
صحت كلى و ضريب كايا، صحت كاربر و صحت توليد كنــده،

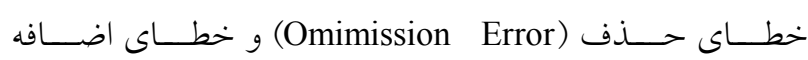
استفاده شد.

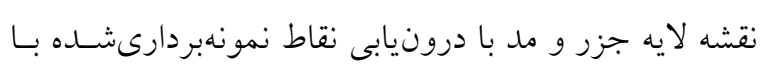

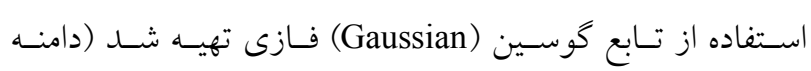

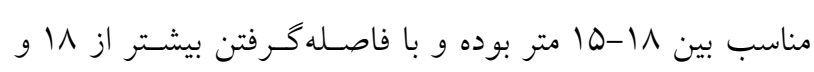

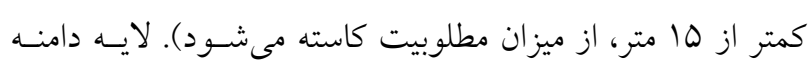

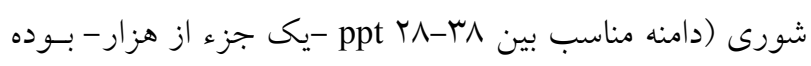

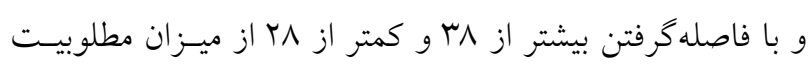

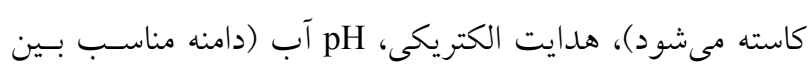

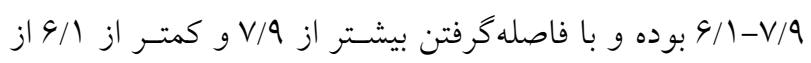

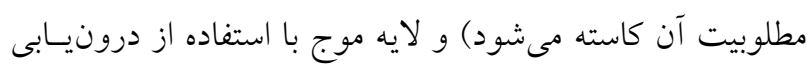

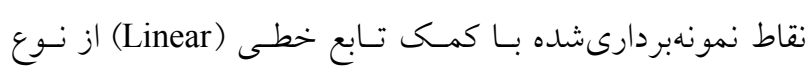

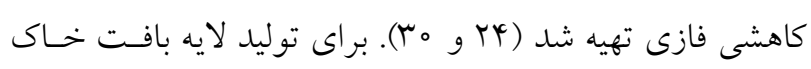

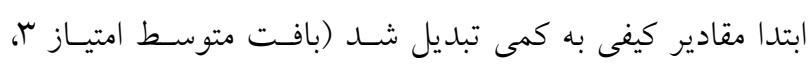

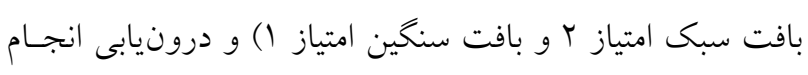

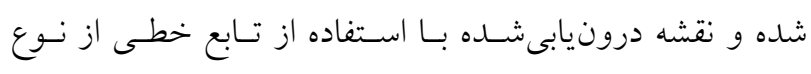
افزايشى، فازى شد. نقشه شيب با بهكارگيرى مدل رقومى ارتفاع

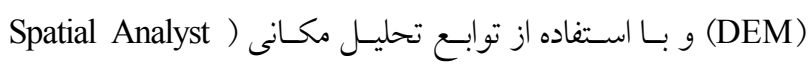
(Tools استخراج نقشه هيسومترى از DEM منطقه استفاده شد كه نشان

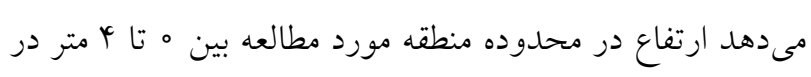

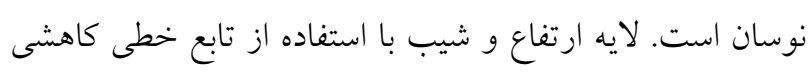

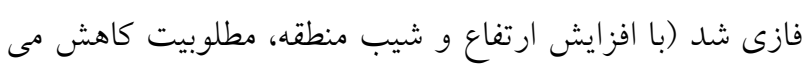

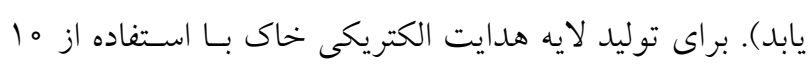


جدولr. شاخص ساز گارى براى مقايسه معيارها (YV)

\begin{tabular}{|c|c|c|c|c|c|c|c|c|c|}
\hline 9 & $\wedge$ & V & 9 & 0 & r & r & r & 1 & $\mathrm{a}_{\mathrm{Bw}}$ \\
\hline D/T & $\varphi / 4 V$ & $r / N r$ & $r / \circ \circ$ & $r / \mu_{0}$ & $1 / 94$ & $1 / \circ \circ$ & $0 / Y^{p}$ & $\circ / \circ \circ$ & شاخص سازگارى \\
\hline
\end{tabular}

اولويت بهترين معيار نسبت به بدترين معيار هستند. از آنجا كـه

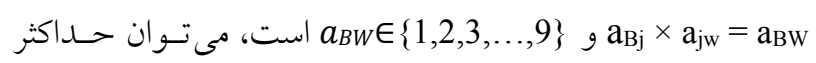

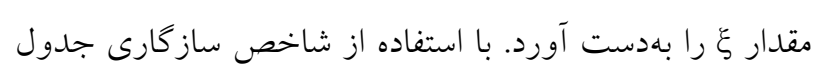

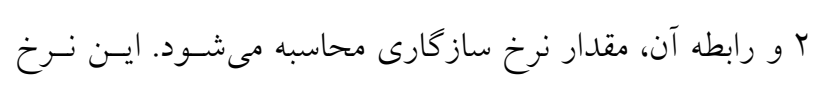

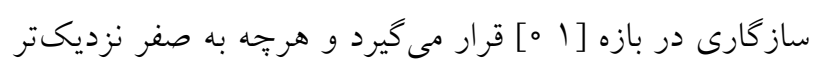

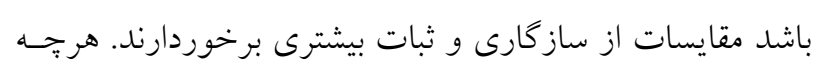
اين نرخ به يك نزديكتر باشد مقايسـات از سـازكارى و ثبـات شاخص سازگارى

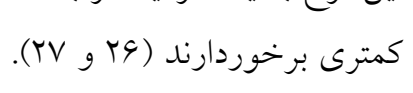

اين مدل توسط برنامه نوشتهشده در نرمافـزار لينگـو (LINGO) حل شد. تلفيق لايهها با روش وزندهى افزودنى ساده

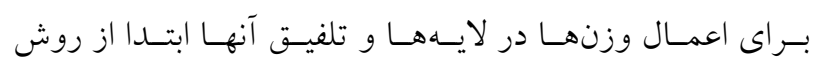

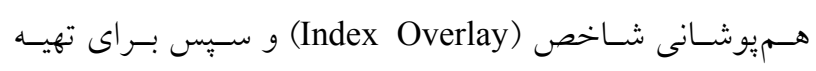

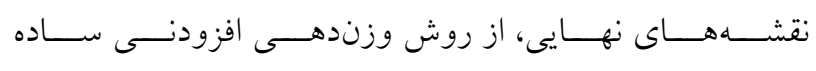
(Simple Additive Weighting)

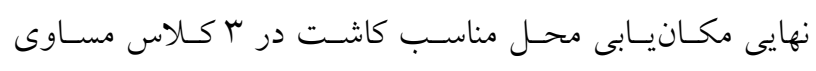
(Equal Intervall) مناسب، و مناسب) طبقهبندى شد.

$$
\sum w_{j}=1, A i=\sum_{j=1}^{n} W j \times X i j
$$

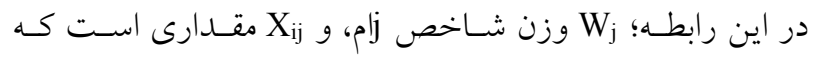
مكان أام به خود اختصاص داده است. بهعبارت ديخر اين مقدار

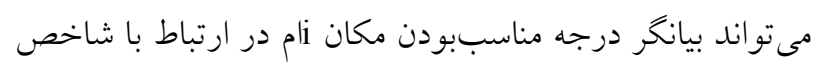

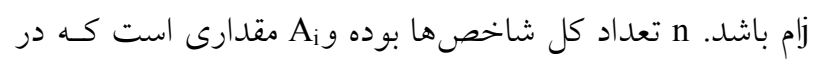

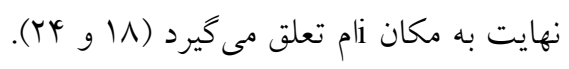

$\frac{\mathrm{W}_{\mathrm{b}}}{\mathrm{W}_{\mathrm{j}}}=\mathrm{a}_{\mathrm{Bj}} \quad, \quad \frac{\mathrm{W}_{\mathrm{j}}}{\mathrm{W}_{\mathrm{w}}}=\mathrm{a}_{\mathrm{jw}}$

براى برقرارى اين شرايط براى تمام j ها، حسـاكثر تفــاوتهـاى

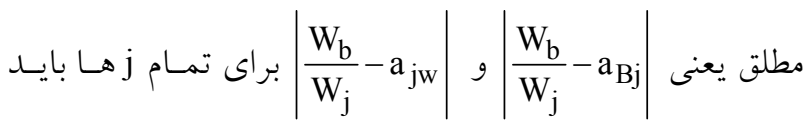
حداقل باشد. با درنظر كرفتن منفى نبودن مقادير و شرايط جمع اوزان، رابطه 9 بهدست مى آيد. $\min \max _{\mathrm{j}}\left\{\left|\frac{\mathrm{W}_{\mathrm{b}}}{\mathrm{W}_{\mathrm{j}}}-\mathrm{a}_{\mathrm{Bj}}\right|,\left|\frac{\mathrm{W}_{\mathrm{b}}}{\mathrm{W}_{\mathrm{j}}}-\mathrm{a}_{\mathrm{jw}}\right|\right\}$

s. t.

$\Sigma w j \mathrm{j}=1$

$\mathrm{W}_{\mathrm{j}} \geq 0$, for all $\mathrm{j}$

براى تمام ز ها رابطه 9 مىتواند به مسئله زير (رابطه V) تبديل شود.

$\min \xi$

s.t .

$\begin{array}{ll}\left|\frac{W_{b}}{W_{j}}-a_{B j}\right| \leq \xi & \text { براى تمام } 1 \text { براى تمام joا }\end{array}$

$\Sigma w j j=1$

براى تمام j ها

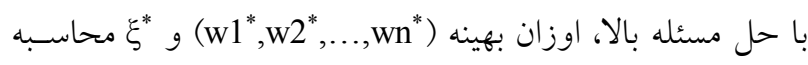

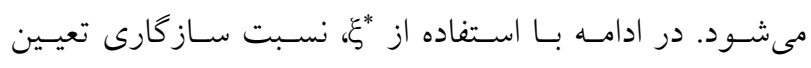

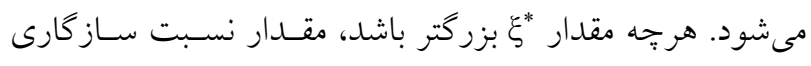

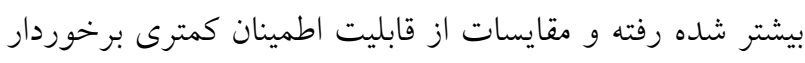

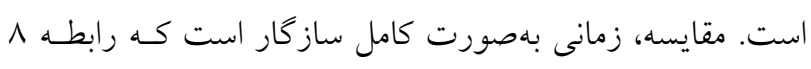

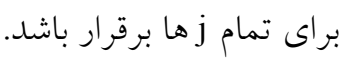

$\mathrm{aBW}=\mathrm{ajw} \times \mathrm{aBj}$

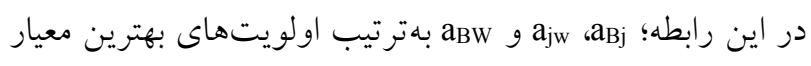

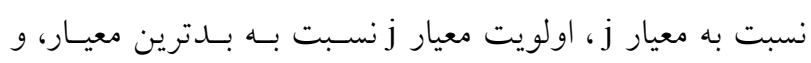


هارامتر كاياست. ضريب كايا برعكس روش صحت كلى، ميـزان

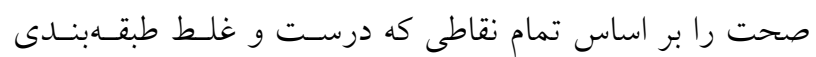

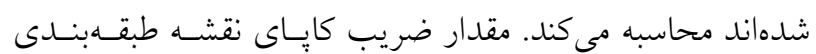

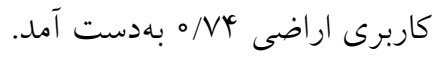

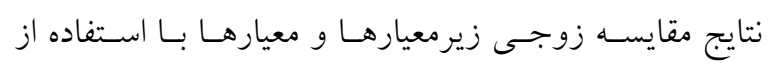
روش بهتـرين - بــترين (BWM) نشـان داد كـهـ از نظـر معيـار

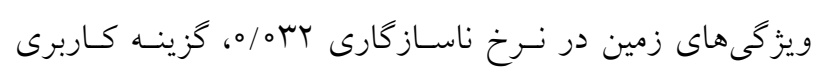

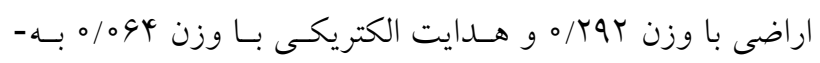

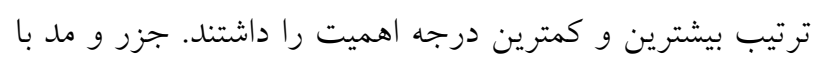

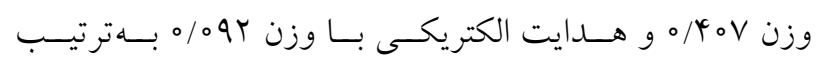

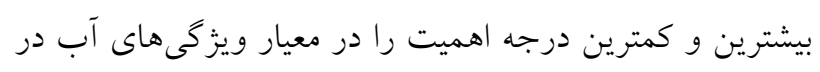

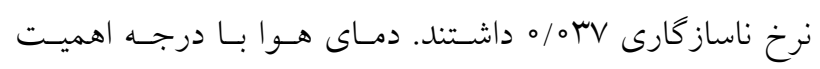

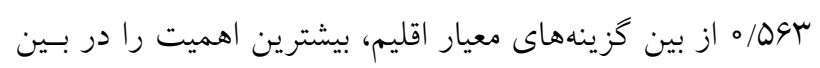

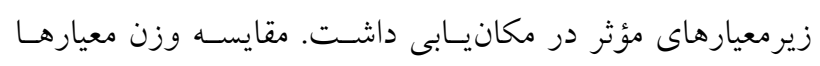

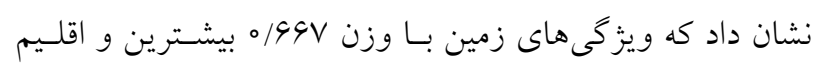

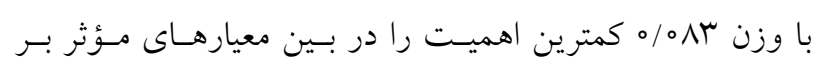

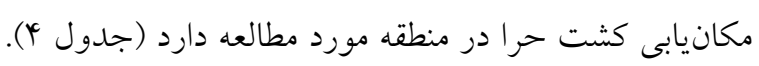

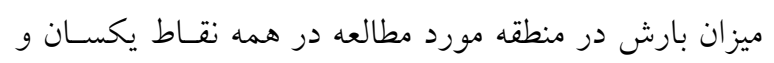

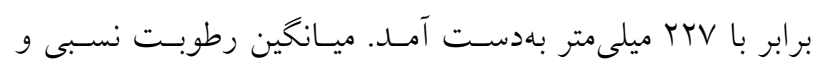

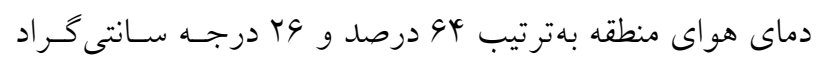

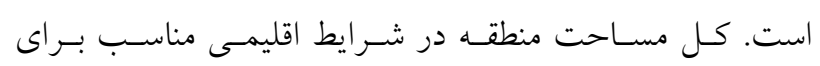

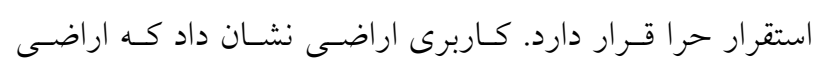

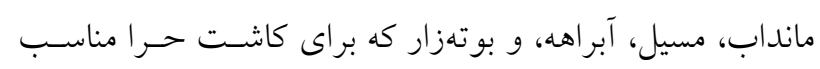

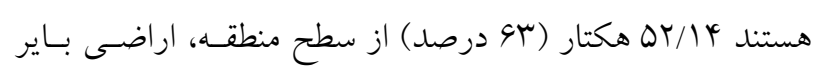

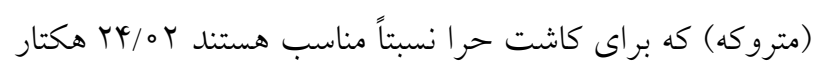

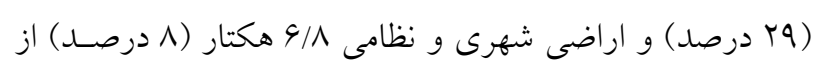

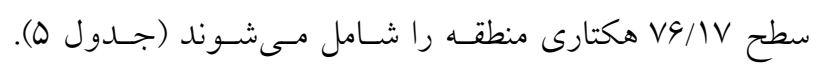

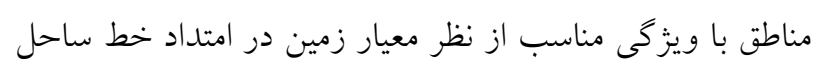

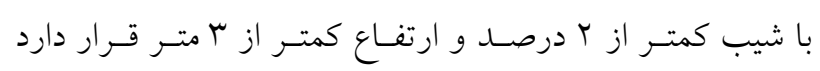

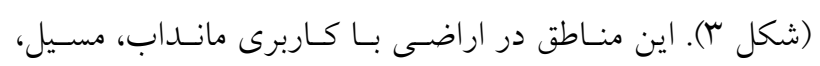

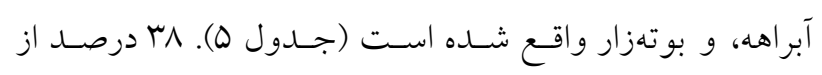

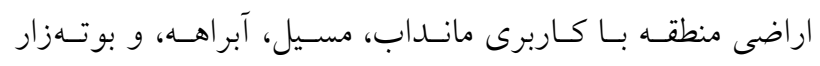

ارزيابى صحت نقشه مكانيابى توليدشده

ارزيابى صحت نقشه نهايى مكانيابى، با همبوشـانى (Overlay) نقشه توليدى حاصل از مكانيابى و نقشه واقعيت زمينى (تهيـهـ -

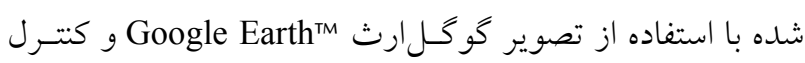

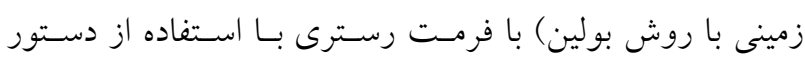

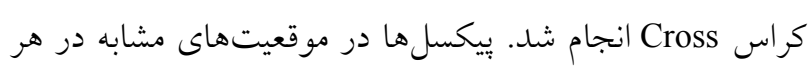
دو نقشه مقايسه شدند. مقادير بيكسل ها در نقشه توليدى مكان ماندان

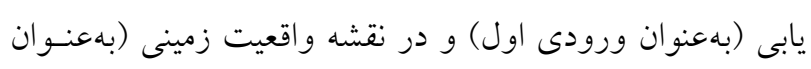

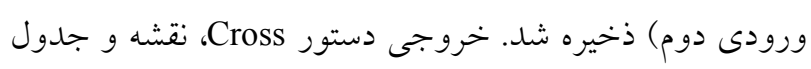

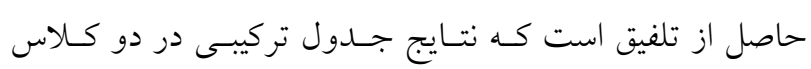

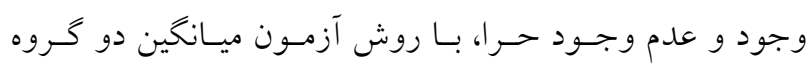

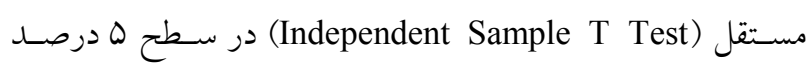
(p<0/0ه)

نتايج

نتايج ماتريس خطاى نقشـه كـاربرى اراضسى بـهدسـت آمــه از

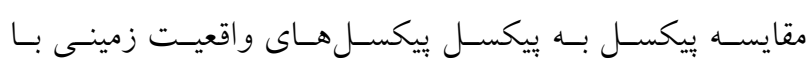

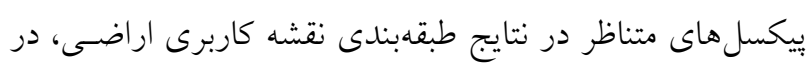

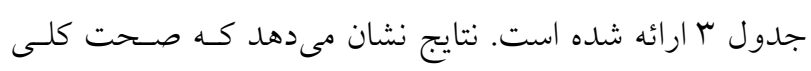

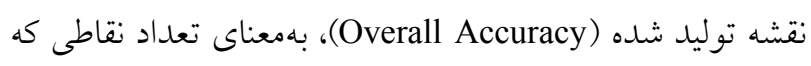

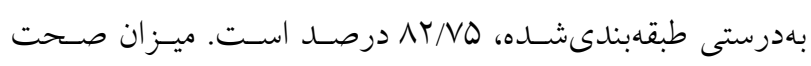

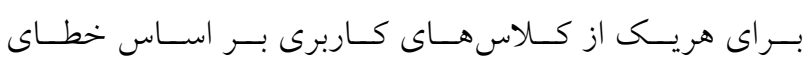

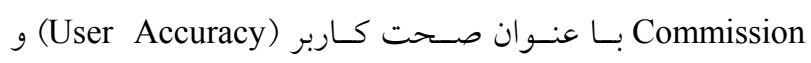

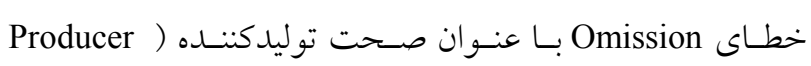
(Accuracy

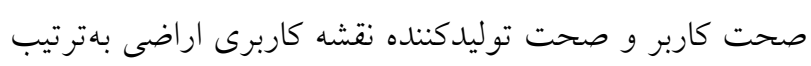

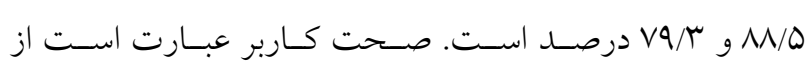
احتمال نقاط طبقهبندى شده بهطور صحيح، و صحت توليدكننده

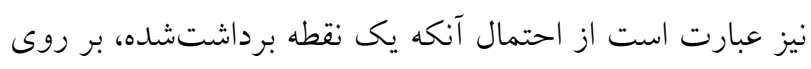

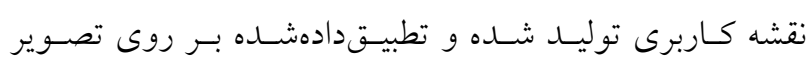

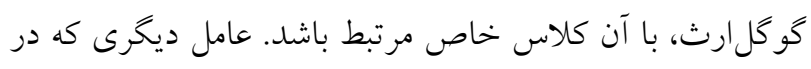

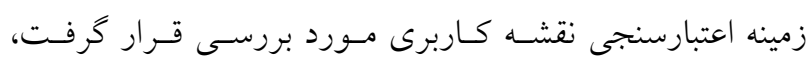




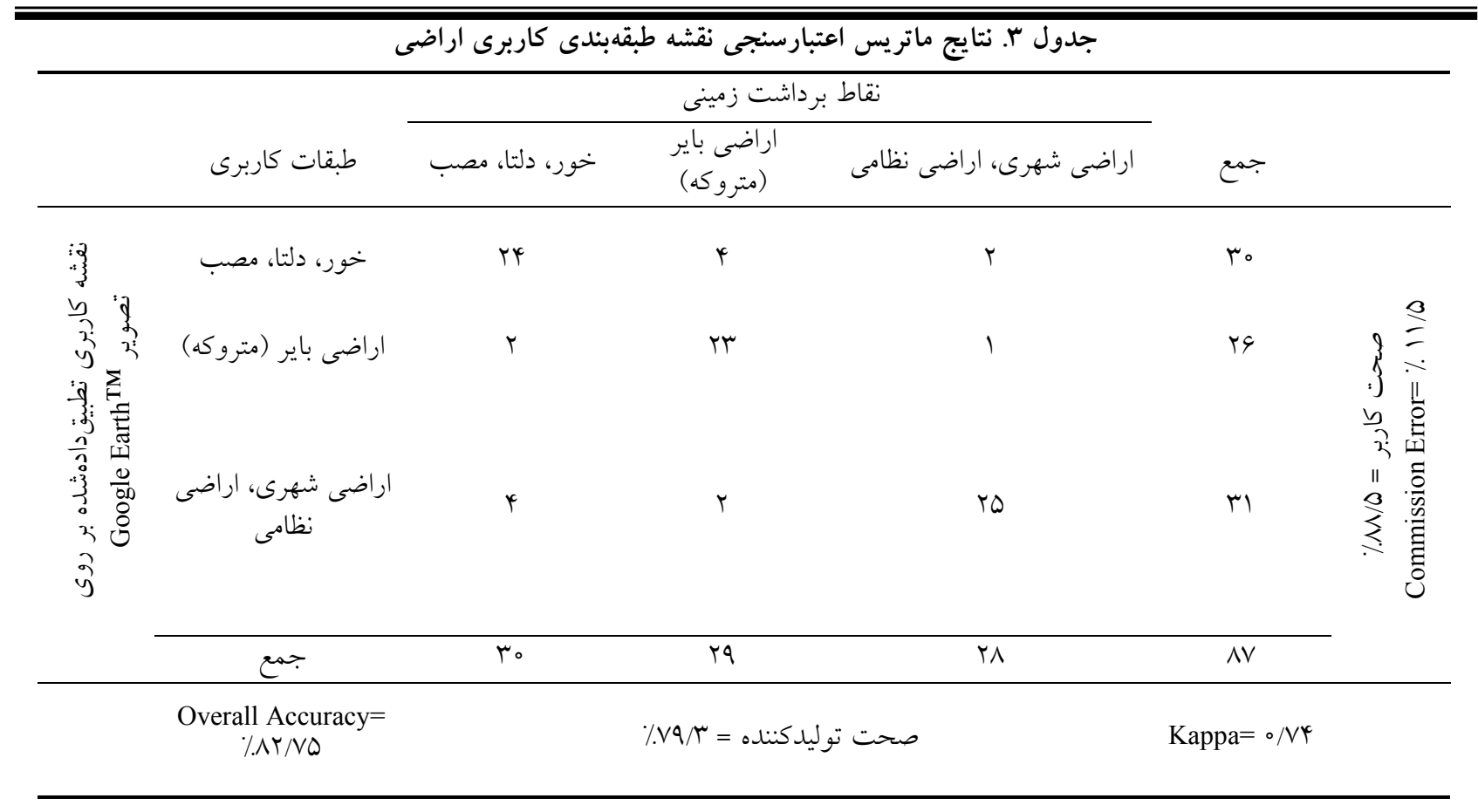
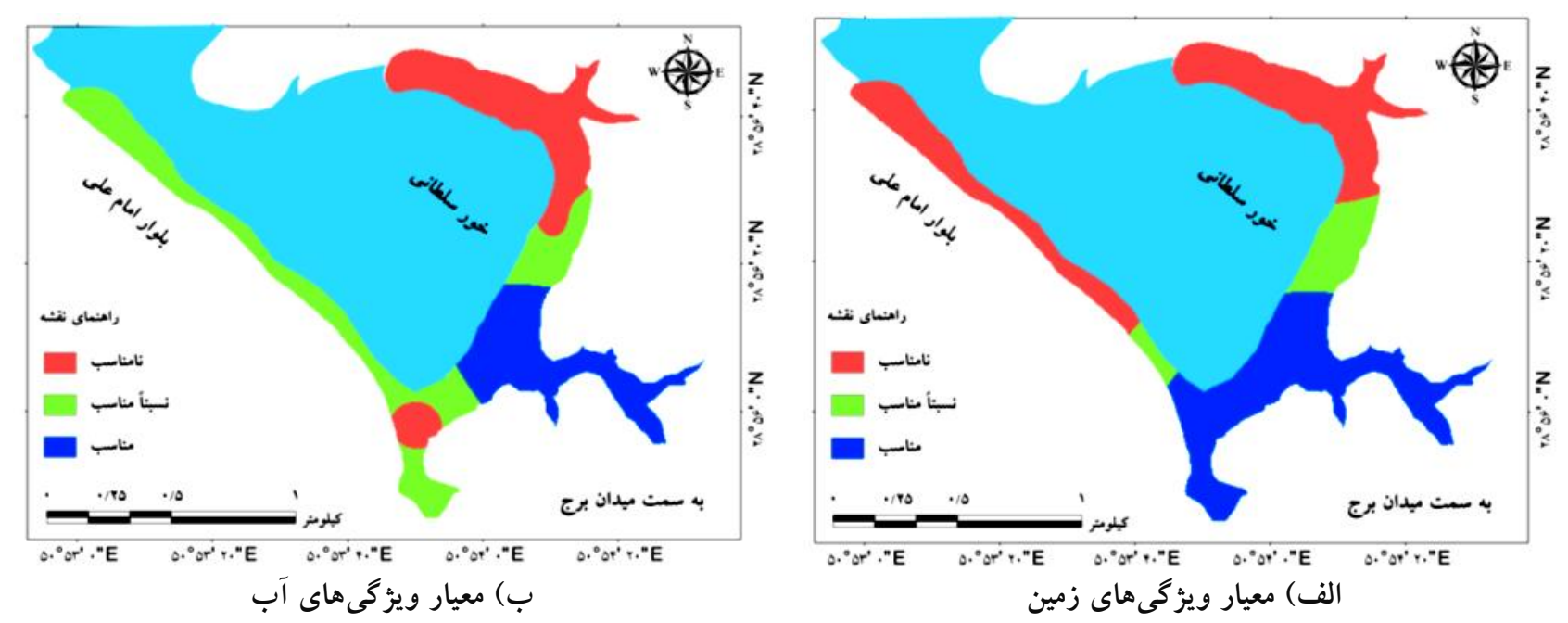

شكل r. نقشه شايستخى معيارهاى مؤثر در كاشت حرا (رنكى در نسخه الكترونيكى)

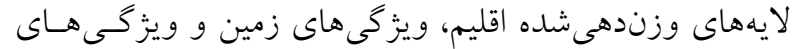

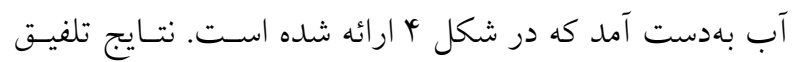
نهايى معيارها و زيرمعيارهاى مؤثر در مدل نشان مىدهـد كـه

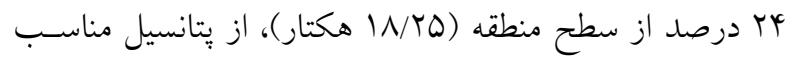
براى كاشت حرا برخوردار است. مساحت و درصــ مسـاحت

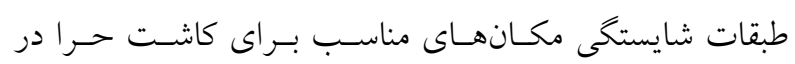
جدول 9 و موقعيت مكانى مناطق در شكل ع ارائه شده است.

\section{نتايج ارزيابى صحت نقشه توليدشده}

ارزيابى صحت نقشه مكانيابى توليدشده در مقايسه بـا نقشـه

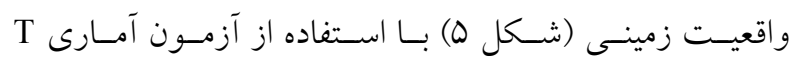

ساحلى، از نظر كيفيت خاك در طبقه شايستخى مناسـب قـرار

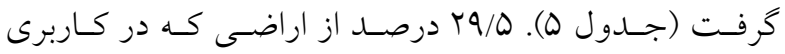
مانداب، مسيل، آبراهه، و بوتهزار قرار گرفتهاند تحت بوشـش بـ جزر و مد آب دريا، براى كاشت حـرا مناسـبند. حسـود ه/N/ درصد از اراضى بهدليل تغيير در خط ساحلى و سـاختوسـاز در منطقه جذر و مدى، مناسب كاشت حرا هستند (جــدول ه، شكل ب). از ميان سه معيار مؤثر بــر مكــانيـابى محـل كاشـت حرا، محدودكنندهترين عامل ويزگ كىهاى آب منطقه است.

نقشه نهايى تلفيت معيارها طبقهبندى منـاطق مســاعد بـراى كاشـت حـرا يـس از تلفيـق 
جدول \&. نتايج ماتريس مقايسه زوجى و وزن زيرمعيارها و معيارهاى مدل

\begin{tabular}{|c|c|c|c|c|c|c|c|}
\hline معيار ويزگى هاى زمين & كاربرى اراضى & بافت خاى & هدايت الكتريكى & نوع خاك & شيب & ارتفاع & وزن \\
\hline كاربرى اراضى & 1 & $r$ & $r$ & $r$ & $r$ & $r$ & - TTar \\
\hline بافت خاى & $1 / r$ & 1 & $r$ & r & r & r & $0 / 191$ \\
\hline هدايت الكتريكى & $1 / 4$ & $1 / \pi$ & 1 & $1 / r$ & $1 / r$ & $1 / r$ & $0 / 044$ \\
\hline نوع خاك & $1 / r$ & $1 / r$ & r & 1 & 1 & 1 & $0 / 191$ \\
\hline شيب & $1 / r$ & $1 / r$ & $r$ & 1 & 1 & 1 & $0 / 191$ \\
\hline ارتفاع & $1 / \pi$ & $1 / \pi$ & r & 1 & 1 & 1 & $0 / 191$ \\
\hline
\end{tabular}

نرخ سازگارى

\begin{tabular}{|c|c|c|c|c|c|c|}
\hline معيار ويزَكى هاى آب & جزر و مد & شورى & هدايت الكتريكى & $\mathrm{pH}$ & موج & وزن \\
\hline جزئ و مد & 1 & $r$ & $r$ & $r$ & $r$ & $\circ / 4 \circ V$ \\
\hline ل شورى & $1 / \Gamma$ & 1 & r & 1 & $1 / r$ & 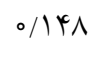 \\
\hline هدايت الكتريكى & $1 / 4$ & $1 / r$ & 1 & 1 & $1 / r$ &.$/ 094$ \\
\hline $\mathrm{pH}$ & $1 / r$ & 1 & 1 & 1 & $1 / r$ & $0 / N r$ \\
\hline ل موج & $1 / r$ & r & r & r & 1 & OMYY \\
\hline
\end{tabular}

\begin{tabular}{|c|c|c|c|c|}
\hline معيار اقليم & بارش & رطوبت نسبى & دماى هوا & وزن \\
\hline بارش & 1 & $r$ & $1 / r$ & $0 / \mu I r$ \\
\hline رطوبت نسبى & $1 / \pi$ & 1 & $1 / 4$ & - /TSD \\
\hline دماى هوا & $r$ & $\varphi$ & 1 & ०/DGM \\
\hline
\end{tabular}

\begin{tabular}{|c|c|c|c|c|}
\hline معيارها & ويزگَىهاى زمين & ويزگى هاى آب & اقليم & وزن \\
\hline ويزگى هاى زمين & 1 & $r$ & V &.$/ 99 \mathrm{~V}$ \\
\hline ويزگى هاى آب & $1 / \pi$ & 1 & $r$ & $\circ / T Q_{\circ}$ \\
\hline 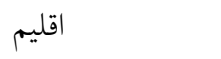 & $1 / N$ & $1 / 4$ & 1 & $\circ / \circ \wedge r$ \\
\hline
\end{tabular}

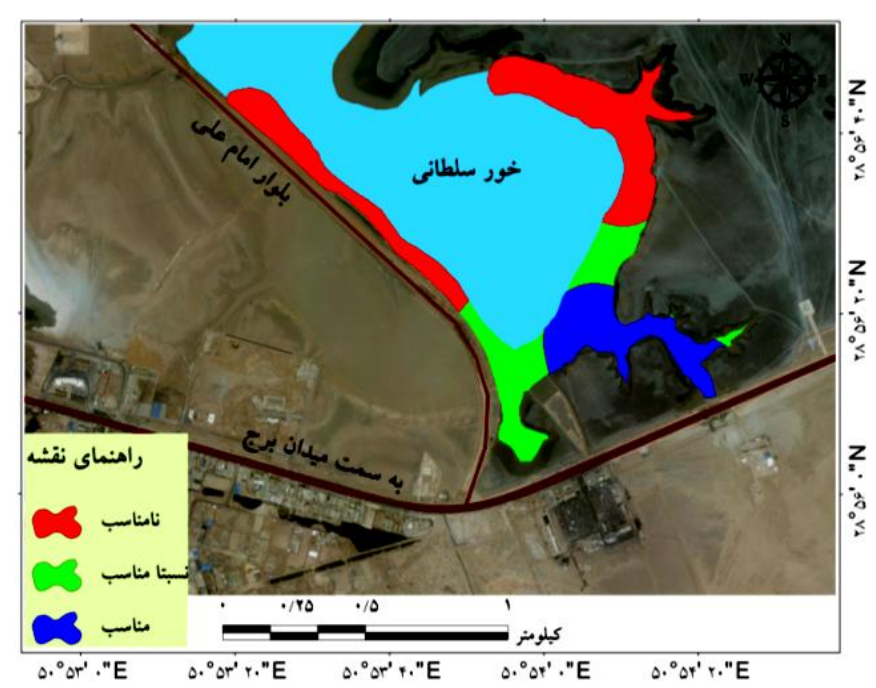

شكل f. مكانهاى مناسب كاشت حرا در منطقه مورد مطالعه (رنكى در نسخه الكترونيكى) 
جدول ه. مساحت و درصد مساحت طبقات شايستگى كاربرى اراضى براى كاشت حرا از نظر معيارهاى مختلف

\begin{tabular}{|c|c|c|c|c|c|c|}
\hline \multicolumn{2}{|c|}{ c } & \multicolumn{2}{|c|}{ نسبتاً مناسب b } & \multicolumn{2}{|c|}{ a مناسب a } & \multirow{2}{*}{ زير معيارهارها } \\
\hline درصد & هكتار & درصد & هكتار & درصد & هكتار & \\
\hline$r \Delta / 1$ & $T V / l$ & $r \circ / V$ & 19 & $K \psi / Y$ & $\mu \varphi / r$ & معيار ويزَگىهاى زمين \\
\hline$\wedge$ & $9 / 1$ & rq & $T Y / O T$ & q & $\Delta T / / T$ & كاربرى اراضى \\
\hline$r I / 4$ & 19/Tr & $10 / 1$ & V/V & $9 \Lambda / 0$ & $\Delta Y / T Y$ & شيب \\
\hline 90 & $\varphi \Delta / V_{0}$ & Tr/TG & $\mathrm{IV} / \circ \mathrm{r}$ & $1 V / 94$ & Ir/4r & ارتفاع \\
\hline rT/ & $Y Y / D \Lambda$ & $\mu \circ / \phi$ & (T/KG & $r V / r$ & TN/Tr & بافت خاى \\
\hline $01 / 4$ & $\mathrm{rq} / \mathrm{lV}$ & $V / 4$ & $0 / 90$ & $4 \backslash / 1$ & س & نوع خاى \\
\hline $\mathrm{rq} / \mathrm{V}$ & r./T & rM/AG & $1 \mathrm{~N} / \mathrm{V}$ & re/4te & TV/VQ & هدايت الكتريكى \\
\hline$\uparrow 1 / \wedge 0$ & MI/M & TG/FY & ro/ & $M / N 1$ & $Y \Psi / T O$ & معيار ويزگ گیىاى آب \\
\hline$\varphi_{0}$ & $\mu \circ / V \circ$ & ro & TS/9V & rY & $1 \wedge / 0$ & جزر و مد \\
\hline$r \Delta / q r$ & TV/TV & $T Q / T Q$ & 19/Tr & 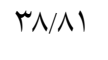 & $r 9 / 09$ & موج \\
\hline $01 / V G$ & $r q / 4 r$ & $Y \Psi / T V$ & $11 / 49$ & $r r / 99$ & $1 N / T D$ & شورى \\
\hline $\mathrm{rq} / \mathrm{V}$ & r./T & TH/AG & $1 \mathrm{~N} / \mathrm{V}$ & re/4te & TV/VQ & هدايت الكتريكى \\
\hline$\langle 1 / 09$ & MI/99 & $r \mu / K$ 。 & IV/AY & $r \Delta / \circ \Gamma$ & rG/91 & $\mathrm{pH}$ \\
\hline- & - & - & - & 100 & $V G / I V$ & معيار اقليم \\
\hline- & - & - & - & 100 & $\mathrm{VG/IV}$ & بارش \\
\hline- & - & - & - & 100 & $\mathrm{VG} / \mathrm{IV}$ & رطوبت نسبى ساليانه \\
\hline- & - & - & - & 100 & $\mathrm{VG} / \mathrm{IV}$ & دماى متوسط ساليانه \\
\hline- & - & - & - & 100 & $\mathrm{VG/IV}$ & حداقل مطلق دما \\
\hline- & - & - & - & 100 & $\mathrm{VG} / \mathrm{IV}$ & حداكثر مطلق دما \\
\hline
\end{tabular}

"aسيار مناسب؛ با كمترين زمان و سرمايه كذارى، امكان توسعه و كاشت حرا در اين مناطق وجود دارد.

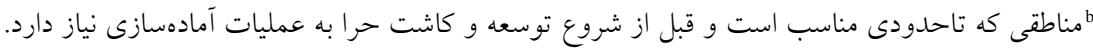

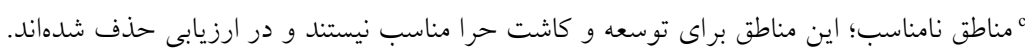
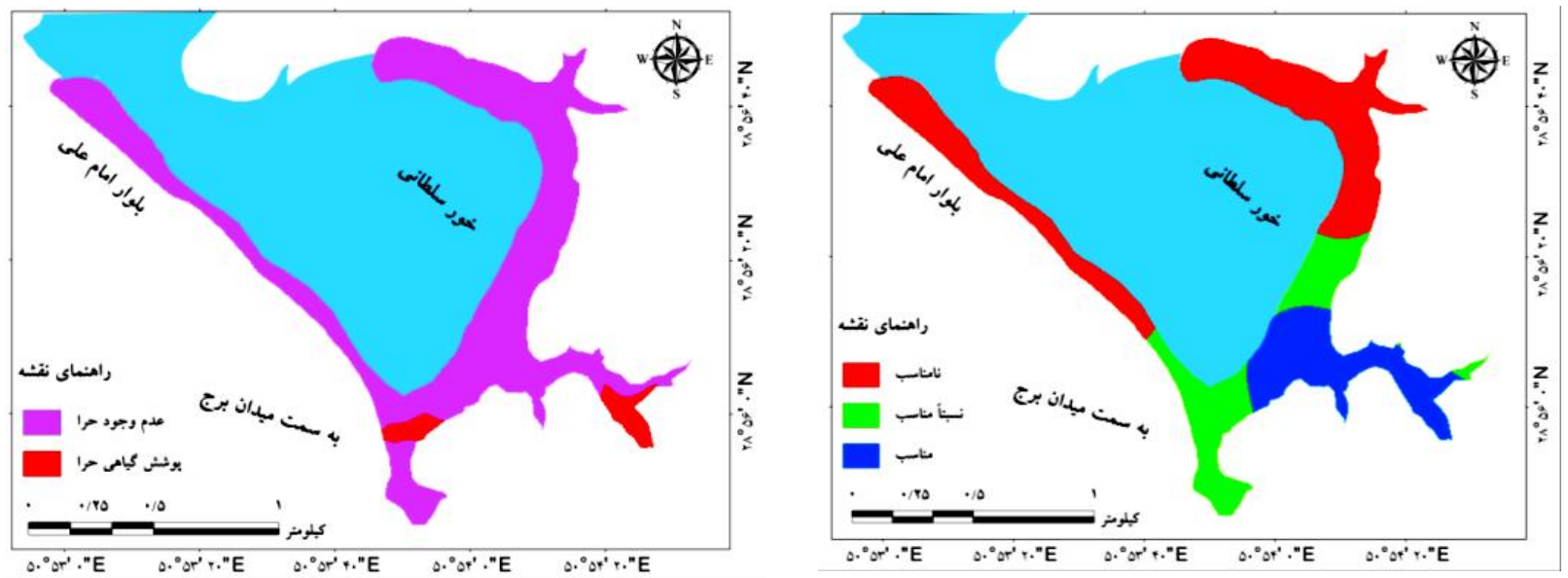

شكل ه. نقشه مكانيابى محل كاشت حرا و نقشه بولين واقعيت زمينى (رنخى در نسخه الكترونيكى) 


\begin{tabular}{|c|c|c|c|}
\hline نامناسب & نسبتاً مناسب & مناسب & شايستخى \\
\hline$r q / 4$ & $1 / 10$ & IN/TQ & مساحت (هكتار) \\
\hline $01 / 1$ & $T \& / \mu$ & YY & مساحت (درصد) \\
\hline
\end{tabular}

يك زمان محدود و خشكبودن ساير ماهها شرايط نامساعدى را براى رشد و توزيع جنخل هاى مانگرو ايجاد مى كند. با توجه بـه مطالعات صورت كرفته در ايسن زمينـه، اسـتان بوشـهر از جملـه اسـتانهـاى كـم بــارش كشـور اسـت و ايسن عامـل در توسـعه جنخالهاى حرا هم اثر مستقيم و هم اتـر غيرمستقيم دارد (Y9). دماى هوا عامل بسيار مهمى در استقرار مانخرو است بهنحوى كه مناطقى كه در آنها دماى سالانه هوا بالا و دامنه تغييـرات دمـايى كمتر از ه ا درجه سانتى گر اد است براى رشد مانكروها مطلـوب است. در محدوده مورد مطالعه، ميانخين دمـاى سـالانه هـورا بو بـ درجه است كه با توجه به مطالعات كذشـته كـه دمـاى مناسـب

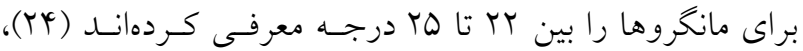
دماى هواى مناسب براى توسعه مانكرو در بوشـهر وجــود دارد. جهار فاكتور آبوهوايى كه بهطور مستقيم بـر روى اكوسيستم هاى مانخرو اثر مى گذارند شامل دماى هوا، يخبندان، بارندگى و مانسون و طوفان هستند. بهطور كلى كونهاى مانكرو در مناطق

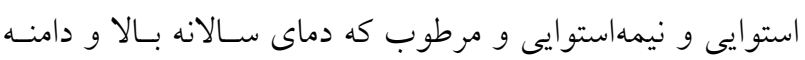
تغييرات دمايى اندك است، يافت مىشوند (ه (1). اقلـيم يكى از عوامل مهم در بر اكنش و استقرار مانخروها بهشمار مىرود، بـهـنحوى كه مانكروها به نوار سـاحلى منـاطق كرمسـيرى و نيمـهـكرمسيرى محدود شدهاند. نامساعد بودن اقليم عاملى اسـت كـهـ موجب تغيير و ازبينرفتن مانخروها مىشود. گونسهــاى بردبـار

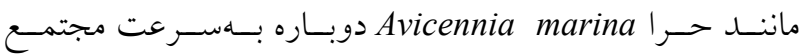
مىشوند، اما اين موضوع در مورد گونهاى ديخر از جنسهـاى Aegiceria و Ceriops ، Sonneratia ،Rhizophora نمى كنـــ. تغييـرات اقليمسى و فعاليـتهــاى انسـانى در مقيـاس منطقهاى و جهانى در نيمكره شمالى، سببشــده كـه وسـعت و تركيب جنگل هاى مانكرو در ايسن منـاطق دسـتخوش تغييـرات اساسى شود. وسعت زياد بهنههاى گلى بين مناطق جزر و مــى
نمونههاى مستقل نشان داد با توجه به مقدار آماره T T( T|0/0) و p-value معنى دار ندارند (جدول V).

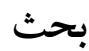

يوشش كياهى در نوار ساحلى شهر بوشهر بهدليل غرقـابى.ـودن اين نواحى و شرايط خشك آب و هوايى، تنسوع كمسى دارد. در سالهاى كذشته، اداره كـل منـابع طبيعى در ورودى شـهر بــهـ صورت الكويى اقدام به كاشت نهالهاى حرا نموده كه در حسال حاضر اين نهالها بهصورت درختجههــيى در ايسن محسيطهـاى

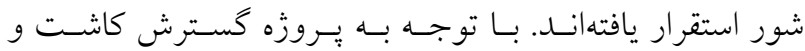
توسعه گونه حرا در نوار ساحلى بوشهر، هدف از ايسن مطالعـه، شناسايى مناطق مستعد كاشت و توسعه حــرا در خـور سـلطانى

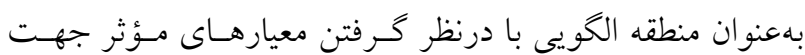

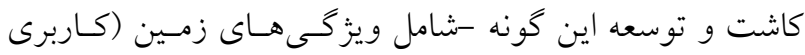
اراضى، شيب، ارتفاع، هدايت الكتريكى خـاك، بافـت خـاك، و نوع خاك)، آب دريـا (دامنـه جـزر و مــد، مـوج، pH، هــدايت الكتريكى، و شورى) و اقليم (دما، رطوبت نسبى، بارش، حداقل و حداكثر دماى مطلق) - است. معيار اقليم شامل زيرمعيارهاى بارش، دماى هـوا و رطوبـت نسبى است. ميزان، مدت و توزيع بارندگى در توسعه گياهـان و

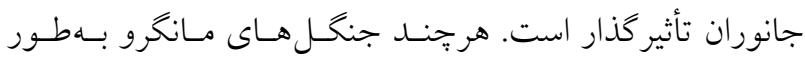
مستقيم تحت تأثير بارندكى نيستند، اما بهسبب شستشوى نمـى از خاك، بارندگى بهطور غيرمستقيم در استقرار مانخروهـا تـأثير دارد (^). در مناطقى كه ميـزان بارنـدگى انـدى اسـت، گياهـان ضعيف و بر اكنده و كوتاهقد مىشوند. بارندگى، غلظت نمـى را در كياه و رسوب تنظيم مى كند و منبعى از آب شـيرين را بـراى كونه هاى مانخرو فراهم مى آورد. در عين حال بارندگى زياد در 
جدول V. نتايج ميزان صحت نقشه شايستخى مكانيابى حرا و مقايسه با نقشه واقعيت زمينى

آزمون ميانخين دو گروه مستقل (Independent sample t test)

\begin{tabular}{|c|c|c|c|c|c|c|}
\hline \multicolumn{7}{|c|}{ آزمون ميانخين دو گروه مستقل (Independent sample t test) } \\
\hline Mean Difference & p-value & df & $\mathrm{t}$ & Sig. & $\mathrm{F}$ & \\
\hline$\circ / 010$ & $\circ / 991$ & r & .014 & $\circ \circ \circ$ & $Y r / T q$ & با فرض مساوىبودن واريانسها \\
\hline$\circ / 010$ & $\circ / 991$ & $1 / 94$ &.$/ 011$ & & & با فرض مساوىنبودن واريانسها \\
\hline \multicolumn{7}{|c|}{ ادامه جدول V ال } \\
\hline \multicolumn{7}{|c|}{ آزمون ميانخين دو كروه مستقل (Independent sample t test) } \\
\hline \multicolumn{4}{|c|}{$95 \%$ Confidence Interval of the Difference } & \multirow{2}{*}{\multicolumn{2}{|c|}{ Std. Error Difference }} & \\
\hline Upper & & Lower & & & & \\
\hline $199 / \mathrm{VA}$ & & $-19 \wedge / \mathrm{NO}$ & & \multirow{2}{*}{\multicolumn{2}{|c|}{$r q / \mu r$}} & با فرض مساوىبودن واريانسها \\
\hline$r \mid r / 94$ & & $-Y \mid Y / 91$ & & & & با فرض مساوىنبودن واريانسها \\
\hline
\end{tabular}

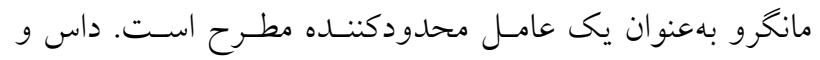
كريين (9) در بررسى اثر امواج ناشى از باد و طوفان بيان كردند

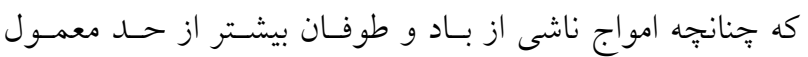
اتفاق بيفتد و يا با شدت زياد ايجاد شود موجب تخريب كونـهـهاى مانخرو مىشود. كليه تعاريفى كه از مانخروها بيان شده آنها را كياهانى متعلق به بهيهن جزر و مدى مىدانند. سواحل با دامنسه جزر و مدى وسيع مىتوانند در كسـترش حضـور جنخـل هـاى مانكرو نقش داشته باشند. وقتى دامنه جزر و مـــى وسـيع مسى شود مناطق زير بوشش جزر و مدى كسترده مىشـود كـه البتـه

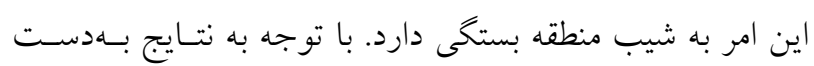

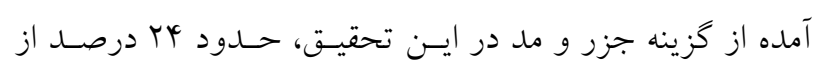

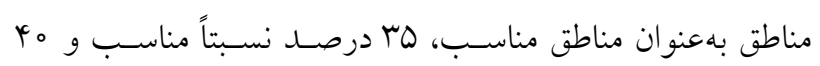
درصد بهعنوان مناطق نامناسب تعيين شد. در گزينه جزر و مــد، مساسب، ساخت و سازها در بيشتر نقاط نمونهبردارى باعـث ازبـينرفـتن سئن

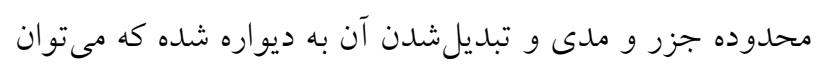
از آن بهعنوان عامل محدودكننده نام برد. مانكروها در شرايط با شورى اندك، انبوهتر مسىشـوند و در شورى بين ه تا هم ppt مستقر مىشوند (9 19). بررسىهـا نشـان

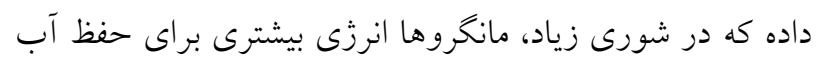

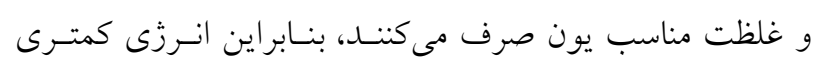

در مناطق نيمه خشك ممكن است محدودهاى را براى انطبـاق و

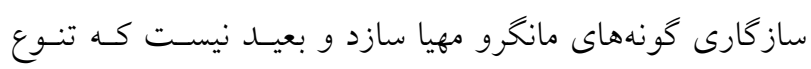
زيستى در جنخل هاى مانگرو در عرضهـاى جغرافيـايى بـالاتر افزايش يابد (سب). جنگل هاى مانخرو بهعنوان يك اكوسيستم سـاحلى، بسـيار تحت تأثير ويزگىهاى آب دريا هستند. زيرمعيارهاى اين معيـار

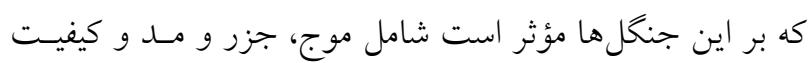
آب دريا است (ب). مانكروها در جـايى مسـتقر مسىشـوند كـه مصون از اتــرات امـواج باشــند. بنـابراين نخسـتين شـرط بــراى

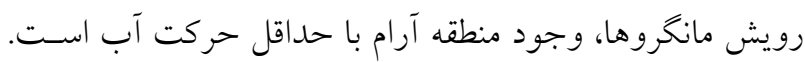
عدم وجود تلاطم و موج به اين معنى است كه آب، فاقد انرزى رون جنبشى لازم براى جابجايى ذرات بـوده و درنتيجـه، ذرات ريسز مىتوانند تهنشين شده و در كف بستر انباشته شـوند. تسهنشـينى رسوبات اجازه مىدهد كه انباشت گل فراهمشده و خاك تحت الارض مانكروهاى مردابى كه عموماً كلـى اسـت شـكل بخيـرد (Y I ( ). در اين مطالعه در مناطقى كه ساحل بهوسيله عواملى مانند ساخت جاده و پيارى تخريبشده، محدوده جزر و مدى از بـين رفته و در هنگام جزر نيز آب به ديواره ساختوسازها برخـورد

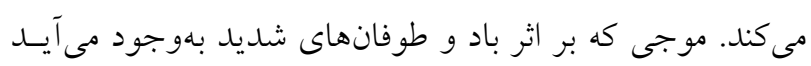
با توجه به موقعيت قرار گيرى منطقه مورد مطالعه، براى درختان 
تراز دريا وجود دارد. بهمحض بـالا رفـتن آب دريـا، فرسـايش

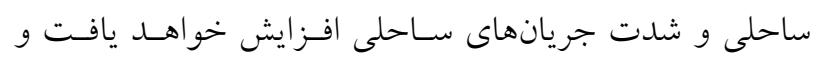

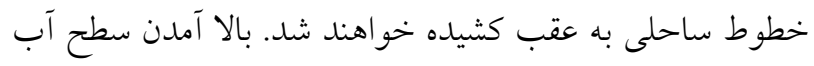
دريا موجب عقبنشينى جنگل هاى مانگرو در بسيارى از مناطق

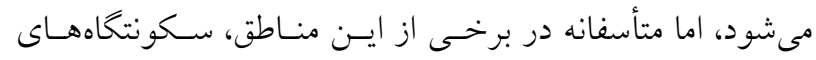

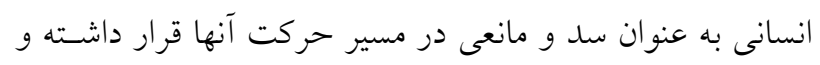

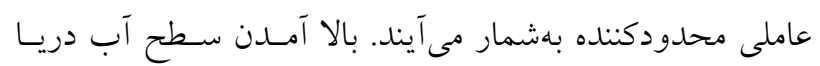

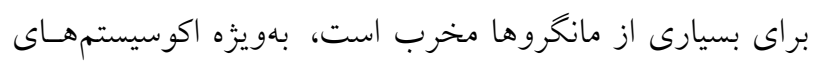

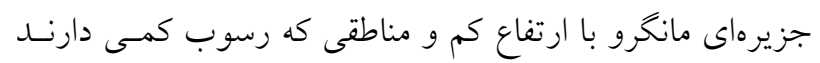

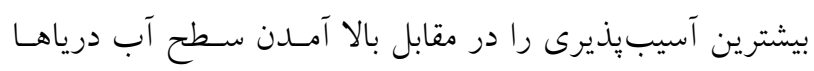
دارند. اكوسيستمهايى كه رسوب زيادى دارند به مانكروها اجازه

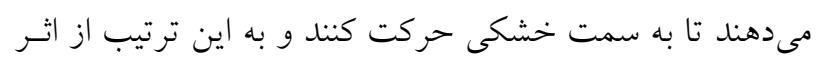

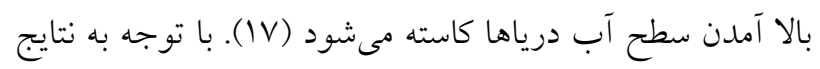

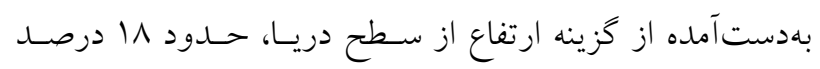

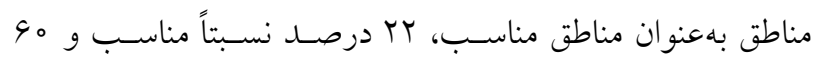

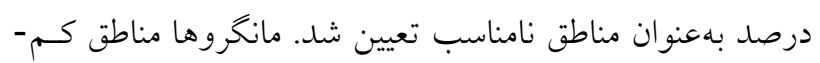
شيب و مسطح با دامنه جزر و مدى وسيع و فعاليت كم امواج را ناطنا

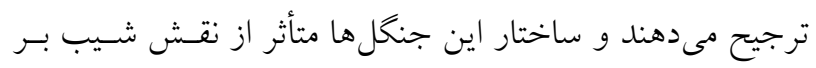

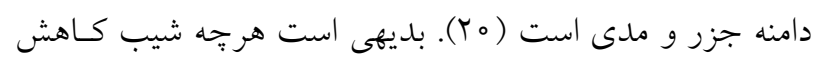

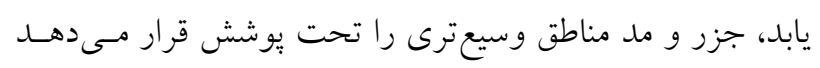

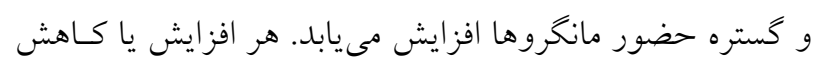

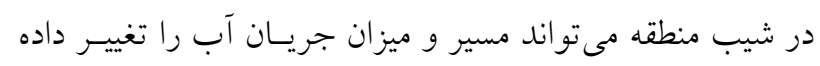

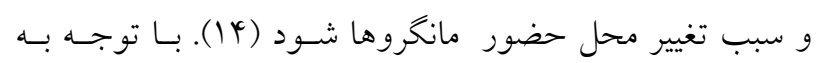

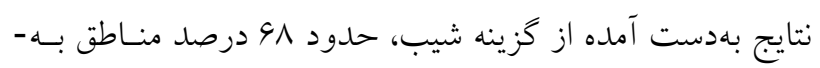

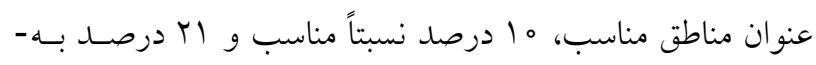

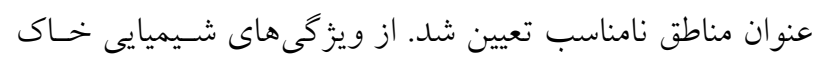

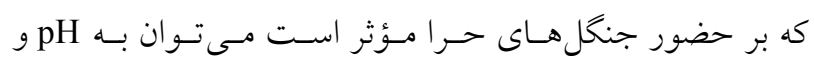

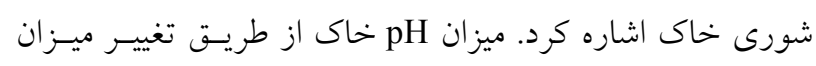
دسترسيذيرى عناصر ضرورى مانند آلومينيوم (كسه ميـزان زيـاد

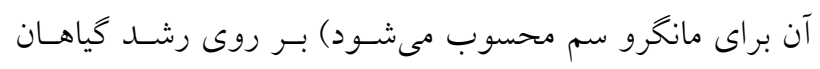

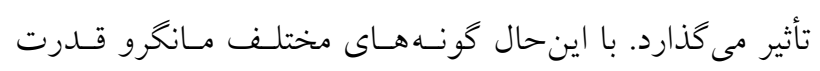

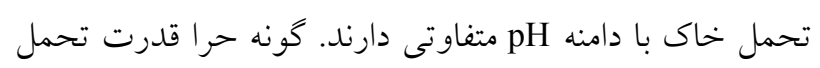

براى رشد و توليدات اوليه باقى مىماند. همجينسين شـورى بـالا

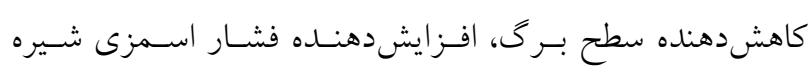

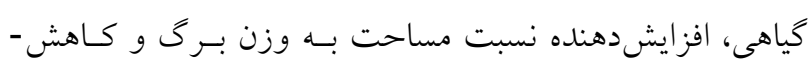

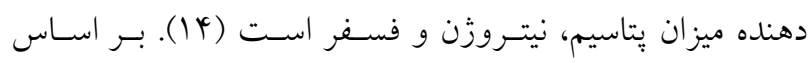

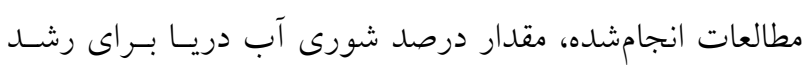

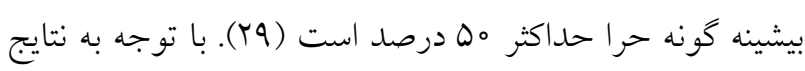

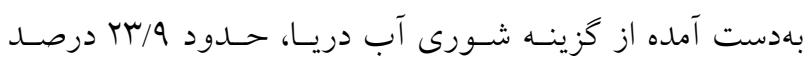

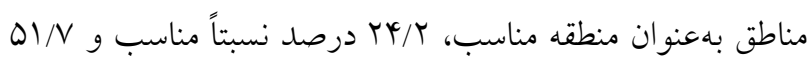

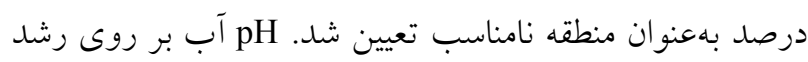

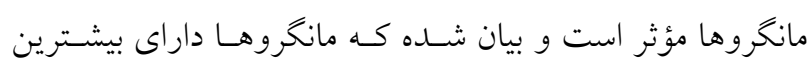

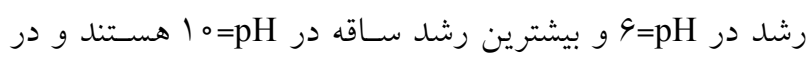

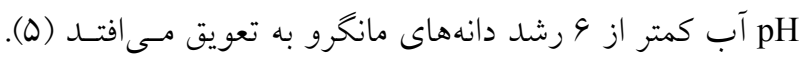

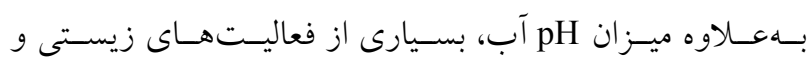

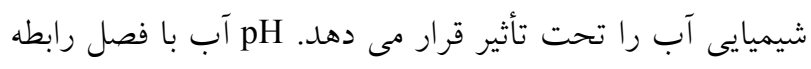

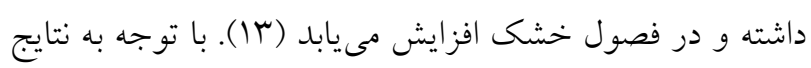

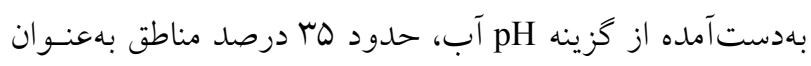

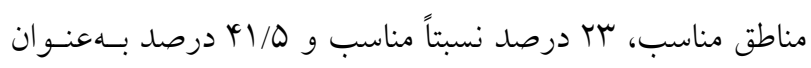

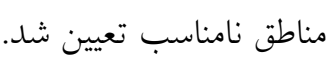

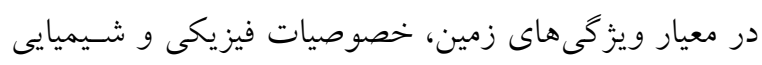

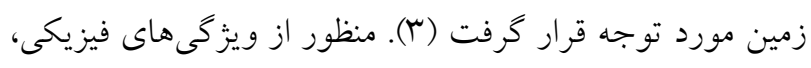

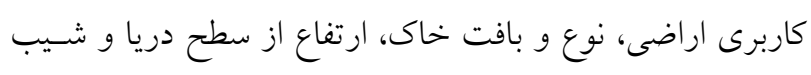

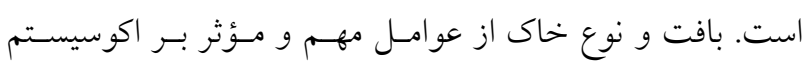

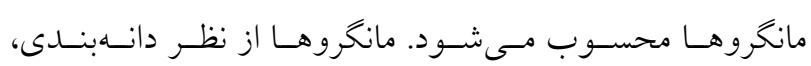

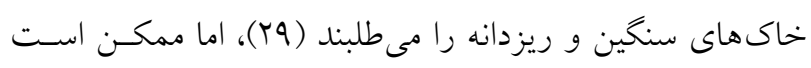

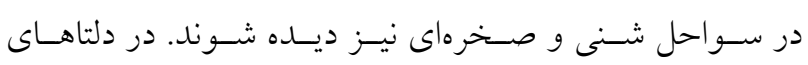

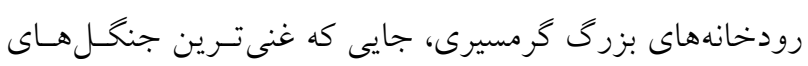

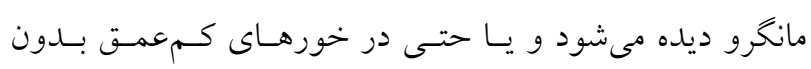

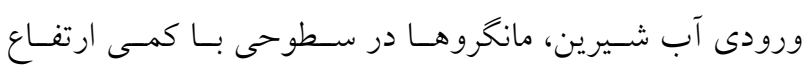

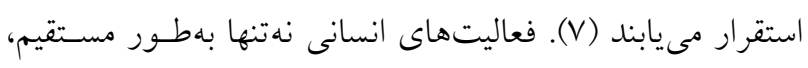

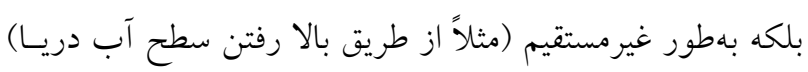

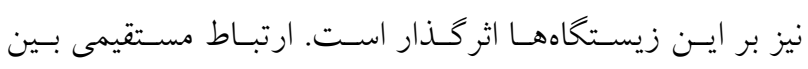

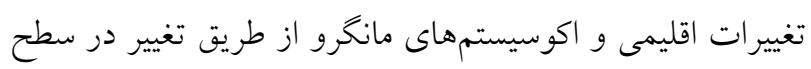


مناطق با شيب نزديك به صفر، خورهاى ساحلى و مناطق جـزر و مدى با ميانخين عمق ا مترى در مد كامل هستند. بر ايسن اسـاس بيشتر مناطق مستعد احيا در جنوب و جنوبشــقى منطقـه مـورد بررسى قرار دارند. بهطور كلى اكوسيستمهاى مـانگخرو نسـبت بـهـ انواع كوناگونى از آشفتخىها و استرسهاى محيطى بسيار آسيب-

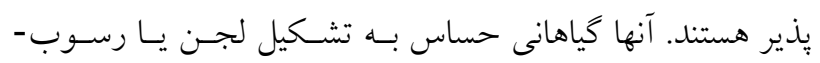
كذارى شديد، ايستابى، آبخيرى آبهاى سطحى و مهمتر از همــه

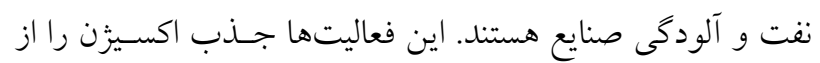
طريق تـنفس كـاهش داده و موجــب افـزايش نـرخ مـرى و ميـر

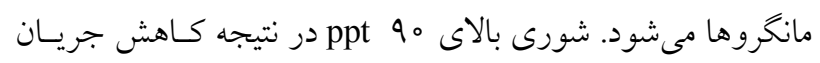
آب شيرين و تغيير الخوهـاى تـراز آب ناشـى از احســاث ســهـا، لايروبى و غيره موجب ازبينرفتن مانخروها مىشود. مهمترين دليل افزايش وسعت مناطق نامناسب جهت ايجـاد جنخل هاى حـرا در منطقـهـ مـورد مطالعـه را مسى تـوان افـزايش ساختوساز از جملـه سـاخت دهكـده خردشـرى و تـأثيرات مخرب آن مانند لايروبى، ازبينرفتن منطقه جزر و مدى و ايجاد ديواره و ساخت جاده در غرب منطقه دانست. در ايستخاههـاى شرقى، عدم آبكرفتكى و صورتنيذيرفتن جـزر و مـــ كامـل،

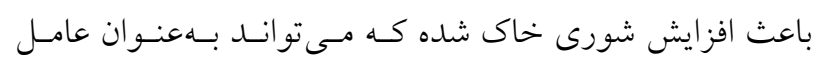
محدودكننده در استقرار و كاشت حرا بهشمار آيد.
خاك با pH بين 9 تا ه/N را دارد و در خاى بـا N/V=pH و ه/ه ه به بيشترين رشد خود مىرسد (9) (1). با توجه به نتـايج بـهدست

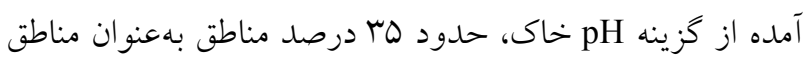

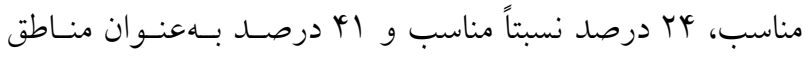
نامناسب تعيين شد. بهطـور كلىى، نتـايج تحقيـق نشـان داد كـــ ساخت و سازهاى ساحلى، توسعه مناطق مسكونى، اسـكلههـا و

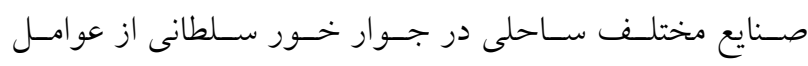
محدودكننده توسعه و كاشت حرا محسوب مىشود. نتيجه گيرى در اين مطالعه مكانهاى كاشـت و توسـعه بوشـشهـاى گيـاهى مانكرو در منطقه مورد مطالعه به ب طبقه تقسيم شـد. منــاطقى كـه. بيشترين ارزش وزنى را داشـتند بـهـــــوان منـاطق داراى بهتـرين كيفيت (مناسب) شناسايى شدند و ساير مناطق بهعنوان منـاطق بـا كيفيت خوب (نسـبتاً مناسـب) و كيفيـت بـــ (نامناسـب) جهـت احياى بيولوزيك بوشـشهـاى مـانگرو در منطقـه تشـخيص داده

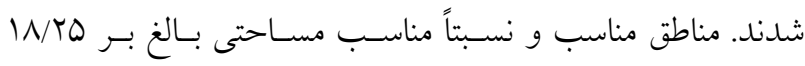

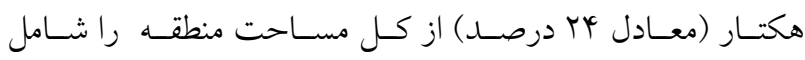

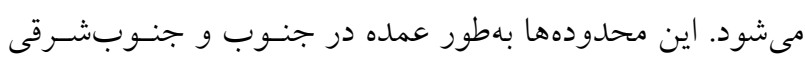

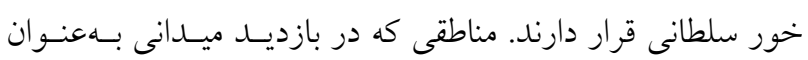
مناطق مستعد احياى بيولوزيك معرفى شدهاند بهطور عمده شـامل

\section{منابع مورد استفاده}

1. Akram, A., A. Alfarhan, E. Robinson and I. Aldjain. 2008. Pattern of survival and mortality of mangrove populations grown at Al-Jubail area (Saudi Arabia) of the Arabian Gulf. American Journal of Agricultural and Biological Science 3(3): 610-616.

2. Amiri, F. and T. Tabatabaie. 2020. The influence of green spaces on land surface temperature and humidity of the surrounding environment in Bushehr city. Environmental Sciences 18(3): 134-160. (In Farsi)

3. Andon Petrosian, H., A. Danehkar, S. Ashrafi and J. Feghhi. 2013. Application of delphi method for prioritization of Mangrove afforestation site selection criteria (case study: Grey Mangroves on north part of Persian Gulf, Iran). Environment and Development Journal 4(7): 37-48. (In Farsi)

4. Berger, U., V. H. Rivera-Monroy, T. W. Doyle, F. Dahdouh-Guebas, N. C. Duke, M. L. Fontalvo-Herazo, H. Hildenbrandt, N. Koedam, U. Mehlig, C. Piou and R. R. Twilley. 2008. Advances and limitations of individualbased models to analyze and predict dynamics of mangrove forests: A review. Aquatic Botany 89(2): $260-274$. https://doi.org/10.1016/j.aquabot.2007.12.015.

5. Bhalla, R., S. Ram and V. Srinivas. 2008. Studies on vulnerability and habitat restoration along the coromandel coast. Publication of UNDP/UNTRS \& FERAL, India.

6. Brunelli, M. and J. Rezaei. 2019. A multiplicative best-worst method for multi-criteria decision making. Operations Research Letters 47(1): 12-15. doi:https://doi.org/10.1016/j.orl.2018.11.008. 
7. Dahdouh-Guebas, F. and N. Koedam. 2008. Long-term retrospection on mangrove development using transdisciplinary approaches: A review. Aquatic Botany 89(2): 80-92. https://doi.org/10.1016/j.aquabot.2008.03.012.

8. Das, G. K. 2013. Characteristics of mangrove substrate sediments of sunderbans. Reason-A technical journal, Vol. XII: 7-18.

9. Das, S. and A. S. Crépin. 2013. Mangroves can provide protection against wind damage during storms. Estuarine, Coastal and Shelf Science 134: 98-107. https://doi.org/10.1016/j.ecss.2013.09.021.

10. Dehghani, M., P. Farshchi, A. Danekar, M. Karami and A. Aleshikh. 2010. Recreation value of hara biosphere reserve using willingness-to-pay method. International Journal of Environmental Research 4(2): 271-280. https://doi.org/ 10.22059/IJER.2010.19.

11. Dehghani, M., M. Pourhashemi, N. Shabanian and Kh. Mirakhorlou. 2014. Identification of suitable sites for development of mangrove forests in Holor region, Qeshm Island. Forest Sustainable Development 1(2): 151-165. (In Farsi)

12. Ellison, A. M. 2008. Mangrove ecology-applications in forestry and coastal zone management. Aquatic Botany 89(2): 77-89.

13. Friess, D. A. 2017. Mangrove rehabilitation along urban coastlines: a singapore case study. Regional Studies in Marine Science 16: 279-289. https://doi.org/10.1016/j.rsma.2017.09.013.

14. Gilman, E. and J. Ellison. 2007. Efficacy of alternative low-cost approaches to mangrove restoration, American Samoa. Estuaries and Coasts 30(4): 641-651. https://doi.org/10.1007/BF02841961.

15. Jafarnia, Sh., J. Oladi and O. Karami. 2013. Application of GIS-AHP in land evaluation for mangrove forest development in Qeshm Island based on physical-chemical water and soil characteristics. Journal of RS and GIS for Natural Resources (Journal of Applied RS \& GIS Techniques in Natural Resource Science) 4(1): 79-91. (In Farsi)

16. Joshi, H. and M. Ghose. 2003. Forest structure and species distribution along soil salinity and $\mathrm{pH}$ gradient in mangrove swamps of the Sundarbans. Tropical Ecology 44(2): 195-204.

17. Kamali, B. and R. Hashim. 2011. Mangrove restoration without planting. Ecological Engineering 37(2): $387-391$. https://doi.org/10.1016/j.ecoleng.2010.11.025.

18. Kaur, L., M. S. Rishi, G. Singh and S. Nath Thakur. 2020. Groundwater potential assessment of an alluvial aquifer in yamuna sub-basin (Panipat region) using remote sensing and GIS techniques in conjunction with analytical hierarchy process (AHP) and catastrophe theory (CT). Ecological Indicators 110: 105850. https://doi.org/10.1016/j.ecolind.2019.105850.

19. Leo, K. L., C. L. Gillies, J. A. Fitzsimons, L. Z. Hale and M. W. Beck. 2019. Coastal habitat squeeze: a review of adaptation solutions for saltmarsh, mangrove and beach habitats. Ocean \& Coastal Management 175: 180-190.

20. Lewis, R. R. 2005. Ecological engineering for successful management and restoration of mangrove forests. Ecological Engineering 24(4): 403-418. https://doi.org/10.1016/j.ecoleng.2004.10.003.

21. Li, W., H. El-Askary, M. A. Qurban, J. Li, K. P. ManiKandan and T. Piechota. 2019. Using multi-indices approach to quantify mangrove changes over the Western Arabian Gulf along Saudi Arabia coast. Ecological Indicators 102: 734-745. https://doi.org/10.1016/j.ecolind.2019.03.047.

22. Nagelkerken, I., S. J. M. Blaber, S. Bouillon, P. Green, M. Haywood, L. G. Kirton, J. O. Meynecke, J. Pawlik, H. M. Penrose, A. Sasekumar and P. J. Somerfield. 2008. The habitat function of mangroves for terrestrial and marine fauna: a review. Aquatic Botany 89(2): 155-185. https://doi.org/10.1016/j.aquabot.2007.12.007.

23. Nazim, K., M. Ahmed, M. U. Khan, N. Khan, M. Wahab and M. F. Siddiqui. 2010. An assessment of the use of Avicennia marina forsk vierh. to reclaim water logged and saline agricultural land. Pakistan Journal of Botany 42(4): 2423-2428.

24. Omo-Irabor, O. O., S. B. Olobaniyi, J. Akunna, V. Venus, J. M. Maina and C. Paradzayi. 2011. Mangrove vulnerability modelling in parts of Western Niger Delta, Nigeria using satellite images, GIS techniques and Spatial Multi-Criteria Analysis (SMCA). Environmental Monitoring and Assessment 178(1): 39-51. doi:10.1007/s10661010-1669-z.

25. Rakotomavo, A. and F. Fromard. 2010. Dynamics of mangrove forests in the mangoky river delta, madagascar, under the influence of natural and human factors. Forest Ecology and Management 259(6): 1161-1169. https://doi.org/10.1016/j.foreco.2010.01.002.

26. Rezaei, J. 2015. Best-worst multi-criteria decision-making method. Omega 53: $49-57$. https://doi.org/10.1016/j.omega.2014.11.009.

27. Rezaei, J. 2016. Best-worst multi-criteria decision-making method: some properties and a linear model. Omega 64: 126-130. https://doi.org/10.1016/j.omega.2015.12.001.

28. Rokni, K. and T. A. Musa. 2019. Normalized difference vegetation change index: a technique for detecting vegetation changes using Landsat imagery. Catena 178: 59-63.

29. Safiari, Sh. 2017. Mangrove forests in Iran. Journal of Iran Nature 2(2): 49-57. (In Farsi).

30. Shahadat Hossain, M. S., C. K. Lin and M. Z. Hussain. 2003. Remote sensing and GIS applications for suitable 
mangrove afforestation area selection in the coastal zone of Bangladesh. Geocarto International 18(1): 61-65. https://doi.org/10.1080/10106040308542264.

31. Sharma, S., R. A. MacKenzie, T. Tieng, K. Soben, N. Tulyasuwan, A. Resanond, G. Blate and C. M. Litton. 2020. The impacts of degradation, deforestation and restoration on mangrove ecosystem carbon stocks across Cambodia. Science of The Total Environment 706: 135416. https://doi.org/10.1016/j.scitotenv.2019.135416.

32. Simard, M., L. Fatoyinbo, C. Smetanka, V. H. Rivera-Monroy, E. Castañeda-Moya, N. Thomas and T. Van der Stocken. 2019. Mangrove canopy height globally related to precipitation, temperature and cyclone frequency. Nature Geoscience 12(1): 40-45. https://doi.org/10.1038/s41561-018-0279-1.

33. Singh, H. 2003. Vulnerability and adaptability of tidal forests in response to climate change in India. Indian Forester 129(6): 749-756.

34. Tilahun, A. and B. Teferie. 2015. Accuracy assessment of land use land cover classification using Google Earth. American Journal of Environmental Protection 4(4): 193-198.

35. Wang'ondu, V., J. G. Kairo, J. Kinyamario, F. Mwaura, J. Bosire, F. Dahdouh-Guebas and N. Koedam. 2010. Phenology of Avicennia marina (forsk.) vierh. in a disjunctly-zoned mangrove stand in Kenya. Western Indian Ocean Journal of Marine Science 9(2): 135-144.

36. Zaldívar-Jiménez, M. A., J. A. Herrera-Silveira, C. Teutli-Hernández, F. A. Comín, J. L. Andrade, C. C. Molina and R. P. Ceballos. 2010. Conceptual framework for mangrove restoration in the Yucatán peninsula. Ecological Restoration 28(3): 333-342. 


\title{
Suitable Site Selection for Avicennia marina Plantation in the Coastal Region of Bushehr, using Best-Worst Multi-Criteria Decision-Making Method
}

\author{
M. Golestani ${ }^{1}$ and F. Amiri ${ }^{\star}$ \\ (Received: August 05-2020; Accepted: May 12-2021)
}

\begin{abstract}
This study was conducted to identify suitable sites for planting Avicennia marina in Soltani Khore of the urban coast of Bushehr. The most effective criteria for Avicennia marina planting include land characteristics (i.e. land use, slope, elevation, soil electrical conductivity, soil texture, and soil type), seawater (i.e. tidal range, wave, acidity, electrical conductivity, and salinity), and climate (i.e. temperature, relative humidity, precipitation, absolute minimum and maximum temperatures) were considered. Ten soil and water samples were collected, using a systematic-random sampling network and their physicochemical variables were measured. The thematic maps of the criteria were prepared and the geographic information system was used to analyse and present spatial data. Using expert opinions and literature review, the priority of the criteria was determined by Delphi method and the criteria were weighted by the Best-Worst method (BWM). Based on the overlay of weighting criteria, using Weighted Linear Combination (WLC), suitable sites for planting and development of Avicennia marina were classified as suitable, relatively suitable and not suitable. The results showed that $24 \%$ (18.25 ha) of the total areas were suitable, $24.3 \%$ (18.5 ha) of the land was relatively suitable, and 51.8\% (39.4 ha) was not suitable for planting and development of Avicennia marina species.
\end{abstract}

Keywords: Avicennia marina, Site selection, GIS, Best-Worst method (BWM), Multi-criteria evaluation, Soltani Khore, Urban coastal zone

1. Department of Natural Resources, Islamic Azad University, Bushehr Branch, Bushehr, Iran.

2. Associate professor, Department of Natural Resources and Environment, Islamic Azad University, Bushehr Branch, Bushehr, Iran.

*: Corresponding Author, Email: famiri@iaubushehr.ac.ir 